\title{
Social comparison of cost behaviour and financial analysts
}

\author{
Oveis Madadian \\ Department of Finance, Audit and Control, IÉSEG School of Management, Lille \& Paris, France \\ o.madadian@ieseg.fr

\section{Walter Aerts} \\ Faculty of Applied Economics, University of Antwerp, Antwerpen, Belgium \\ Tilburg University, Tilburg, Netherlands

\section{Tom Van Caneghem} \\ Faculty of Economics and Business, KU Leuven, Brussels, Belgium \\ University of Antwerp, Antwerpen, Belgium
}

\section{Acknowledgements}

We thank the editor, two anonymous reviewers, participants of the European Accounting Association talent workshop (November 2015, Madrid), the 12th World Congress of Accounting Educators and Researchers (IAAER) (November 2014, Florence) and the 37th Annual Congress of the European Accounting Association (May 2014, Tallinn) for useful comments and suggestions on earlier versions of this paper. We also thank the Research Foundation Flanders (FWO) for financial support (FWO project code G066112N). 


\begin{abstract}
We investigate whether social comparison of a firm's reported selling, general and administrative (SG\&A) expenses affects financial analysts' information uncertainty (and their behaviour). Based on a sample of US firms, we examine whether similarity of a firm's SG\&A to an industry-specific peer-based benchmark (or social benchmark) is associated with analyst forecast dispersion, forecast error and coverage. For external observers, the SG\&A relative to sales (SG\&A ratio) is a key diagnostic of a firm's cost behaviour, but interpretational ambiguity of the SG\&A signal is likely to incentivise search for information-relevant external cues to set expectations about and assess a firm's SG\&A ratio. Higher similarity to the social benchmark is expected to attenuate information asymmetry between analysts and firms regarding firms' ability to effectively control overheads, decreasing analyst information uncertainty about cost behaviour and performance. In line with a varying weights model for social comparison, we observe a negative association between SG\&A similarity and both forecast dispersion and error of one-year-ahead earnings for firms with a prior SG\&A ratio exceeding the social benchmark. Our findings also show a negative relationship between SG\&A similarity and analyst coverage, especially for firms with a prior SG\&A ratio exceeding the social benchmark.
\end{abstract}

Keywords: SG\&A; social comparison; analyst forecast properties; peer-based benchmarking; aspirations 


\section{Introduction}

Social performance feedback rests on social comparison or the use of the performance of a meaningful reference group as a social benchmark (Schimmer and Brauer, 2012, Moliterno et al., 2014). Prior accounting research indicates that social comparison underlies intra-industry information transfers, whereby disclosures of peers in a given industry are seen as informative of conditions at other firms within the industry (Foster, 1981, Gleason et al., 2008). Chalmers and Godfrey (2004) suggest that management may align decisions on prominent but ambiguous reporting issues with industry-based templates, in order to assess or signal appropriateness of underlying behaviour.

In this paper, we argue that the assessment of a firm's Selling, General and Administrative expenses (SG\&A) constitutes such an inherently ambiguous issue, leading financial analysts to use social comparison to assess the appropriateness of reported SG\&A. Social comparison (based on an industry-specific benchmark) is a likely cognitive heuristic for financial analysts to set an evaluative anchor point, when assessing a firm's SG\&A as a fundamental signal. A key theme of behavioural theory on performance evaluationis that social benchmarks are used to make sense of ambiguous performance signals by imposing a normative filter on performance assessment in order to discern desirable from undesirable performance. If analysts infer meaning from social comparison, a firm's SG\&A performance relative to the social benchmark will attenuate information uncertainty. We test this by examining whether and how analyst earnings forecast dispersion, analyst forecast error and analyst following are associated with similarity of a firm's SG\&A ratio (i.e., the ratio of SG\&A over sales) to an industry-specific peer-based benchmark (SG\&A similarity).

US firms disclose SG\&A separately on the face of the income statement and typically discuss SG\&A as a separate topic in the Management Discussion and Analysis (MD\&A) section of their periodic financial reports, indicating a high level of exposure and prominence of the disclosure item. Capital market participants, including financial analysts and external auditors, tend to pick up reported SG\&A as a primary analytic figure when analysing a firm's financial performance. They usually focus on the SG\&A ratio as a key diagnostic of a firm's cost behaviour and resource allocation (Messier, 2000, Healy and Palepu, 2001, Anderson et $a l ., 2007)$. However, a firm's SG\&A ratio is hard to assess, because of uncertainty surrounding interpretation of SG\&A. Several factors feed external observers' uncertainty with regard to the adequacy and appropriateness of a firm's SG\&A ratio: the largely discretionary nature of a 
firm's overhead expense decisions; considerable leeway in accounting rules on allocating indirect expenses; and the asymmetrical behaviour of SG\&A depending on the direction of a change in sales (Mintz, 1994, Lazere, 1995). Prior empirical research (e.g., Anderson et al., 2007, Baumgarten et al., 2010, Johnson, 2013) shows that the interpretation of a firm's change in SG\&A ratio is not straightforward and depends on underlying circumstances and perceived managerial intent. The ambivalence of reported SG\&A is likely to feed financial analyst information uncertainty with regard to appropriateness of firms' cost behaviour.

As information acquisition and processing is costly, financial analysts are likely to follow a logic of consequence, by evaluating reported SG\&A in relation to preset anchor points (Cyert and March, 1963; March, 1994). How decision-makers set their aspiration levels ${ }^{1}$ is a central theme of performance feedback theory (Audia et al., 2015). Performance feedback is not evaluated in terms of absolute outcomes, but rather gradually in reference to preset benchmarks (March and Simon, 1958, Cyert and March, 1963). Prior research on performance feedback centers on a model in which decision-makers set aspiration levels to reflect organisational targets, which are then used as a benchmark for assessing observed performance (Cyert and March, 1963, Greve, 2008). Behavioural decision theory asserts that decisionmakers rely on two types of aspiration level, namely historical and social aspirations (Shinkle, 2012, Washburn and Bromiley, 2012). Historical aspiration levels are set using information about the organisation's own past performance, while social aspiration levels are formed using information about comparable organisations (Audia et al., 2015).

Performance feedback research typically focuses on performance measures that are unequivocal in desirability and for which interpretation of performance feedback is straightforward. For example, when considering return on assets (ROA) as a performance metric, the prima facie assumption of 'the higher the performance score, the better' seems valid and an increase in ROA is likely to be seen as beneficial. This is not the case with SG\&A, for which interpretation of change is more ambiguous and equivocal (a decrease in SG\&A is not necessarily better). This imperils historical performance feedback and promotes the use of social performance feedback as a device to infer meaning with regard to SG\&A performance.

The importance of social comparison is also in line with institutional theory arguments (DiMaggio and Powell, 1983, Deephouse, 1996, Dacin, 1997, Kondra and Hinings, 1998) that,

\footnotetext{
${ }^{1}$ In behavioural decision theory, the term 'aspiration level' is typically used to denote levels of outcomes that satisfy managers. In this strand of literature, the terms 'aspirations', 'targets' and 'goals' are often used interchangeably (Washburn and Bromiley, 2012) and we will do so as well.
} 
in the absence of normative guidelines, organisational agents have strong incentives to resort to social proof of appropriate behaviour as a cognitive heuristic to reduce uncertainty. Social proof is most influential when decision-makers are uncertain about the value and consequences of specific behaviour and when they are able to observe the decisions and behaviour of others (Cialdini, 1993). Imitation of the behaviour of relevant others offers cues that enable other entities to view the behaviour in question as sensible, more appropriate and less risky (Sudharshan et al., 2013).

Based on these considerations, we argue that financial analysts are likely to resort to industry-based peer comparison of target firms as a cognitive heuristic to guide risk assessments, helping them reduce assessment uncertainty. This is especially likely when they consider fundamental but ambivalent items such as reported SG\&A. Analysts are expected to complement historical performance comparison with socially-derived assessments and thus compare a firm's reported SG\&A ratio with social clues (such as SG\&A ratios of peer firms in the focal firm's industry), in order to set expectations of reasonable SG\&A behaviour and normatively draw a dividing line between satisfactory and unsatisfactory performance (Ketchen and Palmer, 1999). If analysts manage to infer meaning from social comparison of a firm's SG\&A performance and detect managerial intent behind SG\&A decisions, social comparison is expected to reduce information uncertainty (i.e., reduce forecast dispersion and error) and affect analyst coverage.

Our results provide evidence of social comparison affecting analyst behaviour. Specifically, we observe that an SG\&A ratio falling below (exceeding) the social benchmark decreases (increases) analyst forecast dispersion. This finding lends support to the argument that an SG\&A ratio falling below (exceeding) the social benchmark decreases (increases) information asymmetry between financial analysts and the firm's management regarding effective cost control and quality of resource allocations. Moreover, results document a negative relationship between SG\&A similarity and analyst forecast dispersion on one-year-ahead earnings, especially for firms with an SG\&A ratio exceeding the social benchmark in the previous period. The association between forecast dispersion and SG\&A similarity holds (and becomes more significant) when change in SG\&A similarity is considered. For firms with an SG\&A ratio exceeding the social benchmark in the previous period, we also document a significantly negative association between change in SG\&A similarity and analyst forecast error. Altogether, these findings suggest that higher SG\&A similarity attenuates analyst information uncertainty, especially when information uncertainty is perceived to be high(er) 
(i.e., when the SG\&A ratio exceeds the social benchmark). Our results show a stronger effect for change in SG\&A similarity compared to the level of SG\&A similarity, which is consistent with findings of fundamental analysis research indicating that especially change in a firm's SG\&A ratio is considered to be a fundamental signal (see e.g., Anderson et al., 2007, Baumgarten et al., 2010, Johnson, 2013).

We also observe a positive relationship between having an SG\&A ratio that exceeds the social benchmark and analyst coverage. Again, this is in line with the argument that having an SG\&A ratio that exceeds the social benchmark increases information asymmetry, providing analysts with more opportunities and benefits of following the firm. In addition, we show a negative relationship between SG\&A similarity and analyst following for firms having an SG\&A ratio that exceeds the social benchmark, suggesting that higher SG\&A similarity reduces information uncertainty and, thus, lowers potential benefits of following the firm.

Overall, our results suggest that higher SG\&A similarity is associated with less uncertainty in analysts' information environment, with the intra-industry benchmark functioning in a pivotal normative role. Analysts are less likely to rely on social comparison when a firm has an SG\&A ratio that falls below the social benchmark, supporting the view that having an SG\&A ratio falling below the social benchmark is interpreted as positive performance feedback. SG\&A similarity is however more prominent in analyst assessments when negative performance feedback prevails (an SG\&A ratio exceeding the social benchmark) and SG\&A similarity is likely to be used to infer intended remedial action.

Our paper adds to prior research on firms' cost behaviour, particularly to research studying implications of cost behaviour for financial analysts' information uncertainty. This is the first paper that focuses on the importance of intra-industry similarity of reported SG\&A from a behavioural theory perspective. While prior studies specifically focus on the implications of change in SG\&A, i.e., comparison against the historical aspiration level (see e.g., Baumgarten et al., 2010, Johnson 2013), we shift the focus of attention to the SG\&A of industry peers (the social benchmark), while we still control for historical comparison feedback. Whereas Baumgarten et al. (2010) refer to the industry average to appropriately assess the information content of a change in SG\&A ratio, they do not provide a detailed motivation, nor do they refer to a theoretical framework to consider the potential relevance of the industry average to assess a firm's SG\&A ratio. In addition, they do not consider a variable related to SG\&A similarity to the industry average, nor do they link (changes in) SG\&A to analyst 
behaviour. Given that analysts' knowledge and information with regard to firms' capabilities in utilising resources is limited, it appears rational for them to look for social signals of appropriateness and to cognitively frame SG\&A as a fundamental signal when predicting earnings. This point has been largely neglected in prior research. In addition, although many studies have explored determinants of financial analysts' earnings forecasts, few studies have focused on the effect of firms' cost behaviour (and SG\&A in particular) (Banker et al., 2014). Results presented in this study focus on how cost behaviour (SG\&A) can be cognitively and normatively framed to enhance external assessments and contribute to filling this research gap.

\section{Theoretical background and hypotheses development}

\subsection{SG\&A ambivalence and social comparison incentives}

Social comparison is likely to be more important for policy issues that are visible and of public concern, but, at the same time, are intrinsically ambiguous and create uncertainty about their consequences (DiMaggio and Powell, 1983, Haunschild, 1993, Greve, 2008). Reported SG\&A reflects these characteristics. SG\&A is a prominent metric in the financial statements of US firms. It is commonly reported as a separate line item in the income statement and figures as a focal discussion topic in the MD\&A section of the quarterly and annual financial reports. It is often commented on in earnings press releases. External users perceive SG\&A as a key diagnostic when assessing a firm's cost behaviour and resource allocation (Messier, 2000, Healy and Palepu, 2001, Anderson et al., 2007).

From a fundamental analysis perspective, (change in) relative SG\&A (or the SG\&A ratio) is typically seen as part of a set of value-relevant fundamental signals (see, e.g., Ou and Penman, 1989, Lev and Thiagarajan, 1993, Abarbanell and Bushee, 1998), that are documented as informative about changes in future earnings (see e.g., Anderson et al., 2007, Baumgarten et al., 2010, Johnson, 2013) and could be incorporated by financial analysts in their forecasting work. In fundamental analysis, increases of relative SG\&A are commonly perceived as management's inability to control costs and inefficient cost management and this is expected to negatively impact future performance (Lev and Thiagarajan, 1993, Anderson et al., 2007, Baumgarten et al., 2010). Conversely, decreases in the SG\&A ratio are interpreted as a sign of tight managerial control over costs and increased efficiency, leading to better future performance. However, empirical evidence does generally not lend support to this view and 
suggests that change in relative SG\&A provides a more ambiguous signal about a firm's performance than the other fundamentals (Abarbanell and Bushee, 1998, Baumgarten et al., 2010).

Evaluation of a firm's SG\&A decisions is not straightforward. SG\&A spending is essential to produce long-term value for a firm by enhancing brand reputation and operating efficiency. Penman (2016) argues that SG\&A expenditures, such as R\&D, promotions, employee training and retention, branding and supply chain development, are expensing investments with uncertain revenues. Optimal levels of relative SG\&A are hard to assess. A restrictive approach to overhead costs ('less is better') may cause under-resourcing of critical activities, resulting in missed growth opportunities, whereas chasing growth at any cost might lead to SG\&A rising to inappropriate levels (Deloitte, 2004). Although determining whether a firm's SG\&A resource allocation adequately supports its strategy is probably an essential input for earnings prediction work, there is no generally accepted model to assess overhead cost effectiveness. Efficiency and effectiveness criteria are, generally, hard to apply to overhead costing, and particularly for external observers.

Managers also have incentives to opportunistically affect SG\&A spending (Roychowdhury, 2006, Gunny, 2010). They may grow firms larger than the optimal size through higher than necessary SG\&A spending, in order to attain higher salaries, bonuses, promotion or commissions (Chen et al., 2012). Alternatively, they may cut SG\&A spending opportunistically to report higher earnings (Gunny, 2010).

At a reporting level, allocation discretion adds to uncertainty with regard to the motives and effectiveness of overhead spending, which further compounds perceived ambiguity of reported SG\&A. SG\&A include many indirect cost items that are allowed to be allocated either to SG\&A or to Cost of Sales (COS) (Mintz, 1994, Lazere, 1995). The Financial Accounting Standards Board (FASB) does not strictly delineate the cost items that firms can relegate to SG\&A (Mintz, 1994). The Securities and Exchange Commission (SEC) also allows considerable flexibility to classify different types of expenses, so that some components of reported SG\&A in one firm may be assigned to COS in another firm. This lack of clear rules allows for considerable SG\&A allocation discretion.

SG\&A have also been shown to behave asymmetrically over time, which complicates ramifications of cost behaviour for earnings prediction (Anderson et al., 2003, Anderson et al., 2007, Weiss, 2010, Chen et al., 2012). Anderson et al. (2003) document that SG\&A decrease less when sales decrease than they increase when sales increase, a phenomenon referred to as 
'SG\&A stickiness'. Anderson et al. (2007) argue that SG\&A stickiness may be caused by both managerial intent and the fixed nature of some SG\&A. In cases where managers, hoping that sales will rebound, maintain costs when sales are decreasing, an increase in the SG\&A ratio reveals positive information about future performance, in conflict with the general expectation of fundamental analysis.

These confounding properties and drivers of reported SG\&A make it difficult for external observers to interpret (change in) a firm's SG\&A ratio, without clues on underlying circumstances and managerial intent. As professional intermediaries, financial analysts are likely to be aware of the inherent ambiguities of reported SG\&A. Lacking clear normative guidelines and transparency of internal SG\&A decision-making, analysts are expected to complement 'historical' performance comparison with 'social' performance comparison, whereby a firm's performance is compared with performance of other firms within its peer group (Panagiotou, 2007, Shinkle, 2012, Washburn and Bromiley, 2012).

\subsection{Social comparison heuristics}

Social comparison benefits can be argued from both an efficient choice and an institutional perspective. Cyert and March (1963) posited that, under conditions of increased uncertainty, decision-makers can economise on search costs by using the collective wisdom of comparable firms to substitute the lack of insight in means-ends relationships. Institutionalists add to this that when the issue at hand has social prominence (for example, when the issue is subject to public concern and perceived as diagnostic by external constituents), the challenge not only resides in making an internally effective choice, but also to make that choice being perceived as intelligible and appropriate (DiMaggio and Powell, 1983, Haunschild, 1993, Deephouse, 1996). The institutional perspective emphasizes the role of conformity, habit and convention rather than instrumentality and agency. The actions of comparable others will define lines of behaviour that can be comprehended and valued. Behaviour is seen as correct in a given situation to the extent that one sees other actors displaying it (Cialdini, 1993). Actions and decisions of peers are considered primary cues that enable decision-makers to assess observed discretionary behaviour as sensible, appropriate or risky.

Both perspectives converge when arguing that a social benchmark functions as a cognitive heuristic to infer expectations of reasonable performance (e.g., reasonable SG\&A levels) and potentially differentiate satisfactory from unsatisfactory cost behaviour to the extent 
that actual SG\&A diverges from the social benchmark. A socially-constructed benchmark to compare a firm's performance will distill consensual target behaviour (Moliterno et al., 2014), with increasing similarity towards the benchmark signalling appropriate action and reducing perceived uncertainty with regard to underlying behaviour.

Behavioural theorists often view social benchmarks in an asymmetric configuration with the anchor point functioning in a pivotal normative or evaluative role. They argue that an aspiration level is likely to transform a continuous performance measure into a dichotomous variable of success or failure (March and Simon, 1958). Such a dichotomous classification simplifies the decision-making process considerably (see Cyert and March, 1992, pp. 172-4), as it determines that performance exceeding some level is deemed to be seen as satisfactory or acceptable, while this falling below as undesirable. The normative function of the social benchmark cognitively translates the anchor point as a borderline between what actors perceive as success or failure, with failure driving management's actions to adjust performance (Schimmer and Brauer, 2012). In line with this, Kim et al. (2015a) argue that social benchmarks help managers assess how well they should minimally perform, because stakeholders will expect the firm to perform at least as good as comparable other firms (Kim et al., 2015a). From this perspective, a social SG\&A benchmark confers meaning to SG\&A decisions by setting a cap to appropriate SG\&A management and by identifying a territory where SG\&A behaviour is no longer seen as successful or satisfactory. Such an evaluative dichotomy is expected to facilitate SG\&A decision-making (Cyert and March, 1992), by determining where relative SG\&A becomes problematic and where the need for search for remedial action becomes imminent.

Research suggests that firms that perform better than the social benchmark assess their performance differently from those that perform worse than the social benchmark, with firms performing better being much less preoccupied with social targets and even tending to completely ignore social comparison in performance feedback (Bromiley, 1991, Washburn and Bromiley, 2012). Weights assigned to social performance comparison and historical performance comparison in the formation of expected targets then vary with relative performance. Social comparison is argued to be particularly prevalent when a firm's performance is evaluated as falling below the socially-constructed target, as failing to achieve a target performance level is likely to prompt 'problemistic search' (Cyert and March, 1963) and intended managerial action (Shinkle, 2012). Intended performance change is, thus, more likely when prior performance is below rather than above social aspiration levels. When firms 
are performing better than the aspiration level, they are expected to prefer the status quo or strive for slightly better performance but not to endanger their performance relative to the aspiration level (Schimmer and Brauer, 2012, Shinkle, 2012). As such, predictions of behavioural performance feedback theory can be different from those based on institutional arguments due to different views on the normative effect of the social benchmark and on the relative salience of the social anchor point as a target for managerial action.

Social performance clues can also be looked for by external observers (e.g., financial analysts) to infer managerial intent behind (change in) SG\&A, with an asymmetric impact on their assessment of SG\&A decisions, depending on whether the SG\&A ratio falls below or exceeds the social benchmark. Baumgarten et al. (2010), for example, use industry averages to infer whether an increase in SG\&A was intended, with a firm's past SG\&A ratio below the industry average considered as efficient SG\&A cost management.

If the varying weights model of social comparison also holds for financial analysts, social comparison will have a stronger impact on their assessments for firms with performance worse than the social benchmark, i.e. for firms with an SG\&A ratio exceeding the social aspiration level. These behavioural theory arguments suggest that an analysis of the impact of SG\&A similarity on analysts' behaviour without considering the normative function of social comparison does not necessarily lead to better earnings prediction.

\subsection{Industry-specific peer-based comparison}

Prior literature highlights the role of a firm's industry as a primary trait to identify relevant referents (peer firms), in order to compare and judge the firm's decisions and observed behaviour (Dye and Sridhar, 1995, Porac et al., 1995, Porac et al., 1999). As financial analysts specialise in specific industries (Fogarty and Rogers, 2005), they are highly familiar with and knowledgeable about the practices within the industries they specialise in and adjust firms' financial ratios according to industry averages (Lev, 1969). Primary industry characteristics typically define the categories of product and market attributes that affect cost behaviour and are deemed to be diagnostic of many underlying aspects of a firm's business and processes (Porac et al., 1995), including overhead cost behaviour and allocations. An industry-based reference scheme will be particularly relevant when assessing SG\&A, as the relative level of SG\&A is largely industry-specific (Ely, 1991, Lazere, 1996, Roberts et al., 2011). 
Empirical evidence (e.g., Moliterno et al., 2014) does however indicate that organisational decision-makers usually construct meaningful peer groups that are smaller than the entire industry. The literature on peer group determination (Panagiotou, 2007) argues that peer groups comprise firms that follow comparable strategies in terms of key strategic dimensions, with firm size subsuming many economic factors, such as growth, complexity and monitoring, which are also likely to affect SG\&A (Ecker et al., 2011) A large body of research on CEO compensation also indicates that peer firms are typically selected based on similarity in terms of both industry and firm size to the focal firm (e.g., Bizjak et al., 2008, Albuquerque, 2009, Black et al., 2011). De Franco et al. (2012) document that about $98 \%$ of analyst reports in their sample explicitly use a within-industry benchmarking approach and that industry and firm size are factors that analysts take into account to select peer firms.

\subsection{Hypotheses development}

As financial analysts' knowledge with regard to firms' real resource allocation capabilities is limited, they are likely to rely on a social benchmark when assessing firms' SG\&A decisions. To the extent that financial analysts use an industry-specific peer-based benchmark as a socially-constructed target to set consensual expectations for effective SG\&A behaviour, higher similarity of a firm's SG\&A level to the social benchmark leads to lower uncertainty with regard to the firm's SG\&A (Lambert et al., 2012). That is, we expect that financial analysts will consider the social SG\&A benchmark as a cognitive reference point. In what follows, we develop our hypotheses based on three proxies for analyst information uncertainty: (1) analyst forecast dispersion; (2) analyst forecast error; and (3) analyst following.

Analyst forecast dispersion is widely used in the accounting and finance literature as a proxy for analysts' overall level of uncertainty (see e.g., Zhang, 2006, Liu and Natarajan, 2012, Chen et al., 2015). Prior research shows that analyst forecast dispersion reflects information asymmetry between firms and analysts (Barry and Jennings, 1992, Barron et al., 1998). In line with prior literature, we therefore use analyst forecast dispersion as our first proxy for analyst information uncertainty. Given that a smaller gap between reported SG\&A and the social benchmark may be indicative of more effective SG\&A cost control and enhanced resource allocation quality, higher similarity to the social benchmark could provide incremental common interpretation of firm-specific information, reducing analysts' uncertainty. That is, higher SG\&A similarity is likely to tighten the distribution of analysts' beliefs, regarding the firm's future performance. Moreover, if higher similarity reduces analysts' costs of processing and 
interpreting reported SG\&A, it enhances their ability to correctly impound all pertinent information in their earnings assessments and leads to less equivocality and more agreement among them (Lehavy et al., 2011). We, therefore, formulate our first hypothesis as follows:

H1: There is a negative association between $S G \& A$ similarity to the social benchmark and analyst forecast dispersion

We choose analyst forecast error as our second proxy for analyst uncertainty. To the extent that similarity between a firm's reported SG\&A and the social benchmark incorporates public information on the true value of SG\&A behaviour (e.g., the extent of a firm's effectiveness in controlling overhead costs and/or enhancing the quality of SG\&A resource allocation decisions), it mitigates uncertainty surrounding reported SG\&A and also complexity in forecasting earnings. Similarity of SG\&A to the social benchmark is, thus, expected to mitigate error in analysts' earnings predictions. That is, SG\&A similarity is likely to convey incremental interpretations about the firm's SG\&A behaviour that feeds financial analysts' public information, improving their earnings forecast accuracy (Kim et al., 2015b). Based on these arguments, we derive our second hypothesis as follows:

H2: There is a negative association between SG\&A similarity to the social benchmark and analyst forecast error

Our third proxy of analyst information uncertainty is analyst following. Making a prediction about the direction of the effect of SG\&A similarity to the social benchmark on analyst following is not straightforward. Prior literature documents that analysts do not randomly choose firms to follow, but weigh costs and benefits of following a firm (Bhushan, 1989, Raghuram and Servaes, 1997). Higher (lower) information asymmetry between a firm and outsiders tends to increase (decrease) opportunities for profitable private information acquisition activities by financial analysts (Barth et al., 2001, Ahn and Cai, 2005, Lehavy et al., 2011, Lobo et al., 2012). Such opportunities result in more (less) profitable investment recommendations and increasing (decreasing) trading commissions, so that increased (decreased) information asymmetry results in higher (lower) analyst coverage. To the extent that financial analysts rely on a social benchmark to assess firms' SG\&A behaviour, higher similarity of reported SG\&A to the social benchmark leads to lower risk assessment and lower 
information asymmetry with regard to a firm's SG\&A. Since financial analysts compete with information already transmitted to the capital markets by a firm, lower information asymmetry between firms and outsiders (via higher SG\&A similarity) is likely to decrease the personal benefits that are expected to accrue to analysts, resulting in lower analyst coverage. Nevertheless, the uncertainty-reducing effect of higher SG\&A similarity may also facilitate information acquisition for analysts, considerably reduce the overall costs of coverage (i.e., information acquisition, information processing and information interpretation costs) and increase the supply of their services. Thus, we expect a significant association between SG\&A similarity and analyst following, but do not posit a directional expectation. We formulate our third hypothesis as follows:

H3: SG\&A similarity to the social benchmark is associated with the number of analysts following the firm

If the normative effect of the social benchmark dominates and the varying weights model of social comparison holds for financial analyst behaviour, the effect on analyst uncertainty will be asymmetric depending on whether the SG\&A ratio exceeds or falls below the social benchmark.

A firm with an SG\&A ratio exceeding the social benchmark will be perceived as being out of cost control (Baumgarten et al., 2010), raising doubt about the effectiveness of its SG\&A behaviour and inducing need for corrective actions and feeding financial analysts' assessment uncertainty (i.e., aggravating information asymmetry between firms and analysts). ${ }^{2}$ However, an SG\&A ratio falling below the social benchmark will be interpreted as indicative of a firm's success in effectively controlling SG\&A. Such firms are less likely to be guided by other firms in their peer group, as they already outperform their peers in terms of reported SG\&A.

Based on these arguments, the impact of social comparison on analyst uncertainty is likely be stronger for firms with an SG\&A ratio exceeding the social benchmark, as it heightens perceived SG\&A risk and increases the salience of the social anchor point as a cognitive target. Moreover, if taking into account presumed managerial intent behind SG\&A behaviour is key to diminishing assessment uncertainty, negative social performance feedback (i.e. having an

\footnotetext{
2 Financial analysts are expected to have more dispersed beliefs about the cost behaviour and future earnings of a firm with an SG\&A ratio exceeding the benchmark. Predicting future performance and earnings of such a firm is also likely to be more difficult, due to problems in predicting the effect of overhead expense behaviour (including SG\&A).
} 
SG\&A ratio that exceeds the social benchmark) is more predictive of intended managerial action, as it necessitates problemistic search to correct historical performance.

Given the perceived uncertainty- (information asymmetry-) increasing effect of an SG\&A ratio exceeding the social benchmark, the impact of SG\&A similarity on analyst information uncertainty is expected to be stronger for firms with a previous ${ }^{3}$ SG\&A ratio exceeding the social benchmark.

Based on the varying weights model of social comparison, we hypothesise:

H4: The negative association between SG\&A similarity to the social benchmark and analyst forecast dispersion is stronger for firms with an $S G \& A$ ratio exceeding the social benchmark in the previous period

H5: The negative association between SG\&A similarity to the social benchmark and analyst forecast error is stronger for firms with an $S G \& A$ ratio exceeding the social benchmark in the previous period

H6: The association of $S G \& A$ similarity to the social benchmark and the number of analysts following the firm is stronger for firms with an $S G \& A$ ratio exceeding the social benchmark in the previous period

A potential challenge in this study is to control for the effect of alternative (economicsbased) scenarios on the hypothesised associations. In Section 3.3, we discuss how we control for these alternative scenarios.

\section{Research design}

\subsection{Sample and data}

We sample US listed firms from 2002 to 2011. From COMPUSTAT, we select all US firms with available data for SG\&A, net sales and lagged total assets (i.e., all data required to define peer groups and calculate our similarity proxy). Consistent with prior research on SG\&A (e.g., Anderson et al., 2003, Anderson et al., 2007), observations with the following

\footnotetext{
3 The one year lag is consistent with prior literature (see e.g. Washburn and Bromiley, 2012).
} 
characteristics are eliminated: (1) SG\&A larger than net sales; (2) banks, insurance firms and all other financial institutions; and (3) public administrative institutions. In addition, we exclude industries (at two-digit SIC industry code level) that consist of fewer than 44 observations (on an annual basis). ${ }^{4}$ This results in an initial sample of 31,407 observations, that is used to determine our proxy for similarity to the industry-specific peer-based benchmark. The yearly number of observations ranges from 2,155 in 2011 to 3,605 in 2002.

Next, we merge our SG\&A similarity proxy and control variables with data from I/B/E/S (analyst forecast data), CRSP (stock prices on forecast date), Thomson Reuters (data on institutional holdings) and ExecuComp (data on CEO compensation). Our final sample consists of 6,939 up to 9,022 firm-year observations, depending on the specific empirical model used for hypothesis testing. The reduction in sample size results from matching COMPUSTAT data with $\mathrm{I} / \mathrm{B} / \mathrm{E} / \mathrm{S}$ data. Consistent with prior studies (e.g., Irani and Karamanou, 2003, Ciccone, 2005), we only retain firms that are followed by at least two financial analysts.

All continuous variables are winsorized at the top and bottom $1 \%$ of their distributions, to avoid the potential influence of outliers.

\subsection{Measurement of similarity to the industry-specific peer-based benchmark}

Following the literature discussed in Section 2.3, we select peer firms based on both industry and firm size. ${ }^{5}$ In line with prior research (e.g., Albuquerque, 2009, Black et al., 2011, Gong et al., 2011), within each industry (based on 2-digit SIC industry codes), observations are assigned to quartiles in terms of firm size (based on total assets ${ }^{6}$ at the beginning of the accounting period). On an annual basis, firms within the same industry and size quartile are considered industry-specific peers. This approach allows a firm to fall in different size quartiles across years, as firms may undergo a restructuring which may affect their size and thus the industry-size-based peer group to which they belong. For each focal firm, the average practice among its peers (i.e., the average SG\&A ratio of firms within the same industry and size quartile) is then used as the industry-specific peer-based benchmark.

\footnotetext{
${ }^{4} 44$ is set arbitrarily to ensure the presence of at least 11 observations within each peer group. As will be discussed in Section 3.2, firms within each industry are assigned to size quartiles to define peer groups.

${ }^{5}$ Alternative ways of identifying peer firms are used in the literature. Hope and Zhao (2017), for example, identify peer firms based on product similarity.

${ }^{6}$ We also considered market value as a proxy for firm size to select peer firms. Results are not materially affected by using market value instead of total assets.
} 
Consistent with prior research (e.g., Finkelstein and Hambrick, 1990, Deephouse, 1996), we rely on the following equation to determine our similarity score:

$$
D S_{i t}=\frac{A B S\left[\left(\frac{S G \& A}{\text { Sales }}\right)_{i t}-M\left(\left(\frac{S G \& A}{\text { Sales }}\right)_{t}\right)\right]}{S D\left(\left(\frac{S G \& A}{\text { Sales }}\right)_{t}\right)}
$$

where $\left(\frac{S G \& A}{\text { Sales }}\right)_{i t}$ denotes the SG\&A ratio for the focal firm $i$ in year $t . M\left(\left(\frac{S G \& A}{\text { Sales }}\right)_{t}\right)$ and $S D\left(\left(\frac{S G \& A}{\text { Sales }}\right)_{t}\right)$ denote the average and standard deviation of SG\&A ratios in the focal firm's industry-specific peer group.

To transform the obtained dissimilarity score (i.e., the preceding equation results in a dissimilarity score) into a score that captures similarity (or a similarity score, henceforth SIMSCORE), we multiply the obtained scores by minus one. Higher values thus indicate greater similarity between a firm's SG\&A ratio and the industry-specific peer-based benchmark.

\subsection{Empirical models}

We estimate Equation 1 (2) to test $H 1(H 2)$ :

$$
\begin{aligned}
& \operatorname{DISP}_{i t}=\alpha_{0}+\alpha_{1} \operatorname{SIMSCORE}_{i t}+\alpha_{2} \text { HISTCOMP }_{i t}+\alpha_{3} \text { NUMAN }_{i t}+\alpha_{4} \text { SIZE }_{i t}+\alpha_{5} \text { SURPRISE }_{i t} \\
& +\alpha_{6} \text { LOSS }_{i t}+\alpha_{7} \text { LEV }_{i t}+\alpha_{8} \text { VOLATILITY }_{i t}+\alpha_{9} \text { OPCOST }_{i t-1}+\alpha_{10} \text { REM }_{i t} \\
& +\alpha_{11} \text { ACCR_RESID }_{i t}+\alpha_{12} \text { BENCH }_{i t}+\alpha_{13} \text { INFOQUAL }_{i t}+\alpha_{14} \text { BigN }_{i t}+\alpha_{15} \text { OCF }_{i t} \\
& +\alpha_{16} \text { CEO_COMP } i t+\alpha_{17} \text { CEO_HOR }{ }_{i t}+\alpha_{18} \text { EXPERIENCE } E_{i t}+\sum_{j=2002}^{2011} Y E A R_{j} \\
& +\varepsilon_{i t} \\
& \operatorname{ERROR}_{i t+1}=\alpha_{0}+\alpha_{1} \operatorname{SIMSCORE}_{i t}+\alpha_{2} \operatorname{HISTCOMP}_{i t}+\alpha_{3} \operatorname{NUMAN}_{i t}+\alpha_{4} \operatorname{SIZE}_{i t} \\
& +\alpha_{5} \text { SURPRISE }_{i t}+\alpha_{6} \text { LOSS }_{i t}+\alpha_{7} \text { LEV }_{i t}+\alpha_{8} \text { VOLATILITY }_{i t}+\alpha_{9} \text { OPCOST }_{i t-1} \\
& +\alpha_{10} R E M_{i t}+\alpha_{11} \text { ACCR_RESID } D_{i t}+\alpha_{12} \text { BENCH }_{i t}+\alpha_{13} I_{\text {INFOQUAL }}+\alpha_{14} \text { BigN }_{i t} \\
& +\alpha_{15} \text { OCF }_{i t}+\alpha_{16} \text { CEO_COMP } P_{i t}+\alpha_{17} \text { CEO_HOR }_{i t}+\alpha_{18} \text { EXPERIENCE } E_{i t} \\
& +\sum_{j=2002}^{2011} Y E A R_{j}+\varepsilon_{i t}
\end{aligned}
$$

(Detailed variable definitions are included in the Appendix.)

The variable of interest in these equations is SIMSCORE, for which we predict a negative coefficient based on $H 1$ and $H 2$. 
Whether analysts use similarity level or change in similarity as a decision input when predicting future earnings is an empirical question. Drawing on prior research that documents 'change in SG\&A' as a fundamental signal (see e.g., Anderson et al., 2007, Baumgarten et al., 2010, Johnson, 2013), one might argue that change in SG\&A similarity will be more influential in earnings prediction models than the absolute level of SIMSCORE, as it may better capture the dynamics and intentionality of managerial decisions with regard to SG\&A spending. Therefore, we use both a level specification (SIMSCORE) and a change specification $\left(\triangle S I M S C O R E\right.$, being $\left.S I M S C O R E_{t}-S_{I M S C O R E_{t-1}}\right)$ as alternative test variables in our empirical models.

We control for historical comparison (HISTCOMP), as decision-makers are argued to commonly compare current performance against historical performance (Lant, 1992). We include change in the SG\&A ratio (i.e., $S G \&$ A ratio $_{t}-S G \& A$ ratio $_{t-1}$ ) to control for the effect of historical comparison feedback. ${ }^{7}$

In line with prior studies (e.g., Weiss, 2010, Lehavy et al., 2011), we also control for variables found to increase analyst information uncertainty. Specifically, we control for NUMAN and SIZE as proxies for the firm's information environment. Earnings of firms experiencing a larger earnings surprise, reporting a loss and/or more volatile performance are more difficult to predict and we therefore control for SURPRISE, LOSS and VOLATILITY. We also include $L E V$ as a proxy for financial risk.

Differences in firms' business models and managerial intent to engage in earnings management, which affect financial analysts' earnings forecasts (Louis et al., 2013), may drive SG\&A ratios converging to/diverging from the social benchmark. This poses a problem of an omitted correlated variable. ${ }^{8}$ As a firm's economic model (encompassing expenses incurred such as operating expenses) is a core element of its business model (Morris et al., 2005), we control for operating expenses (OPCOST) to avoid the correlated omitted variable problem. ${ }^{9}$ To avoid the same problem with regard to managerial intent, we add three control variables that capture earnings management, being REM (a proxy for real earnings management), $A C C R \_R E S I D$ (a proxy for accruals management) (see Appendix for detailed information about the calculation of these two variables) and BENCH (a variable capturing the effect of

\footnotetext{
${ }^{7}$ Results based on models using relative change in the SG\&A ratio ((SG\&A ratio $-S G \& A$ ratio t-1 $\left._{t}\right) / S G \& A$ ratio $\left.t-1\right)$ are qualitatively similar.

${ }^{8}$ We thank an anonymous reviewer for raising this issue.

${ }^{9}$ OPCOST, being the sum of cost of sales and SG\&A scaled by sales, may also capture the effect of events, such as a restructuring, on changes in SG\&A.
} 
managerial attempts to avoid small losses and small decreases in net income). These variables are likely to feed analysts' uncertainty with regard to the firm's future earnings.

Analyst information uncertainty (and analyst behaviour) may also be affected by managerial intent reflected in the quality of firms' information environment. Such managerial intent may also affect deviations from the social benchmark (i.e., SG\&A similarity). Following (Francis et al., 2005), we therefore include INFOQUAL as an indicator of information quality in our models (see Appendix for detailed information about the calculation of this variable). In line with prior studies (see e.g., Shaw, 2003, Cassell et al., 2015), we also include BigN in our models to control for firms' disclosure quality (which is also an aspect of the quality of firms' information environment), where hiring a BigN auditor is associated with higher disclosure quality. ${ }^{10}$

A deviation of the SG\&A ratio from the social benchmark may also result from agency conflicts and we therefore include three common proxies for managers' empire building incentives (arising from the agency problem), being $O C F, C E O \_C O M P$ and $C E O \_H O R$ (see e.g., Chen et al., 2012).

Finally, we control for EXPERIENCE because more experienced analysts benefit from more systematic and idiosyncratic knowledge (De Franco et al., 2015), affecting the quality of their recommendations and forecasts (Harvey et al., 2011).

To test $H 3$, we estimate Equation 3:

$$
\begin{aligned}
\text { ANALFOL }_{i t}= & \alpha_{0}+\alpha_{1} \text { SIMSCORE }_{i t-1}+\alpha_{2} \text { HISTCOMP }_{i t}+\alpha_{3} \text { INSTHLD }_{i t}+\alpha_{4} \text { SIZE }_{i t} \\
& +\alpha_{5} \text { SURPRISE }_{i t}+\alpha_{6} \text { LOSS }_{i t}+\alpha_{7} \text { LEV }_{i t}+\alpha_{8} \text { VOLATILITY }_{i t} \\
& +\alpha_{9} \text { SALES GROWTH }_{i t}+\alpha_{10} \text { MTB }_{i t}+\alpha_{11} \text { OPCOST }_{i t-1}+\alpha_{12} \text { REM }_{i t} \\
& +\alpha_{13} \text { ACCR_RESID }_{i t}+\alpha_{14} \text { BENCH }_{i t}+\alpha_{15} \text { INFOQUAL }_{i t}+\alpha_{16} \text { BigN }_{i t}+\alpha_{17} \text { OCF }_{i t} \\
& +\alpha_{18} \text { CEO_COMP }_{i t}+\alpha_{19} \text { CEO_HOR }_{i t}+\alpha_{20} \text { EXPERIENCE }_{i t}+\sum_{j=2002}^{2011} Y_{\text {SEAR }} \\
& +\varepsilon_{i t}
\end{aligned}
$$

We also estimate (and report) Equation 3, using current SIMSCORE as the main independent variable.

\footnotetext{
10 Lobo and Zhou (2001) document a negative relationship between disclosure quality and earnings management. Thus, our earnings management variables (i.e., REM, ACCR_RESID and BENCH) also control for the quality of a firm's information environment. Moreover, because Lang and Lundholm (1993) provide evidence of higher disclosure quality for large(r) firms, SIZE could also be considered a control for the quality of a firm's information environment.
} 
Control variables in Equation 3 correspond to the control variables used in Equation 1 and Equation 2. However, we include additional control variables that have been found to be associated with analyst coverage in prior studies (e.g., Lang et al., 2003, Yu, 2008, Yu, 2010, Lobo et al., 2012). Institutional holdings (INSTHLD) may affect both the supply of and demand for analysts' services. SIZE is used as a proxy for the firm's information environment. Because Barth et al. (2001) document that sales growth is positively associated with analyst following, we include SALES GROWTH as an additional control variable. Because firms with a higher market-to-book (MTB) have more investment opportunities (Khan and Watts, 2009) and potential for growth in the future (Li, 2008), we also control for MTB. ${ }^{11}$ Finally, as financial analysts' experience is likely to affect the quality of their forecasting work (Harvey et al., 2011) and their decisions (e.g., whether or not to follow the firm), we also control for EXPERIENCE.

To test $H 4$ up to H6, we estimate Equation 1, Equation 2 and Equation 3 including a dummy variable that is coded one if the firm's SG\&A ratio exceeds the industry-specific peerbased benchmark in the previous period (and zero otherwise) (ABOVE) and its interaction with SIMSCORE (SIMSCORE $\times$ ABOVE). As the main test for the asymmetric effect of social comparison on analyst information uncertainty is based on the interaction between SIMSCORE and $A B O V E$, we also include the interaction between SIMSCORE and the variables representing alternative explanations (to avoid the omitted correlated variable problem). ${ }^{12}$ Specifically, in the models that aim at testing $\mathrm{H} 4$ up to $H 6$, we include interaction terms for $R E M$, $O C F$, CEO_COMP and CEO_HOR with SIMSCORE. ${ }^{13}$

To estimate our models, we rely on ordinary least squares (OLS) regressions using time fixed effects. We implement adjustments for heteroscedasticity and autocorrelation (i.e., we cluster standard errors at firm level). ${ }^{14}$

\footnotetext{
11 In addition, as growth firms (i.e., firms with a higher MTB) are argued to have more complex and uncertain business models (Li, 2008), $M T B$ could also be considered a control for the firm's business model.

12 In the models with $\triangle S I M S C O R E$ and $\triangle S I M S C O R E \times A B O V E$ as the main independent variables (i.e., Model IV of Table 3 and Model VIII of Table 4), we include interaction terms for REM, OCF,CEO_COMP and CEO_HOR with $\triangle S I M S C O R E$.

${ }^{13}$ Inclusion of these interaction terms in the models aimed at testing $H 1, H 2$ and $H 3$ does not materially affect results.

14 To estimate the analyst following model, we alternatively employ the negative binomial and Poisson techniques as the number of analysts following the firm is a positive integer (count data). Results are not qualitatively different.
} 


\section{Empirical results}

\subsection{Descriptive statistics}

Table 1 presents descriptive statistics for the variables used in this study. In addition, Table 1 presents key figures before and after merging data from COMPUSTAT with data from I/B/E/S, Thomson Reuters and CRSP. As shown in Table 1, sample firms are substantially larger for the sample under study than for the original sample retrieved from COMPUSTAT. This observation is in line with prior studies on analyst earnings forecast properties and confirms that larger firms are more likely to be followed by financial analysts. The average absolute amount of SG\&A is also substantially larger for the merged sample than for the original COMPUSTAT sample. Table 1 shows that SG\&A account, on average, for $29 \%$ of net sales (median value 25\%) and they constitute, on average, $30 \%$ of total expenses (median value $26 \%)$. For the dependent variables, we note that analyst forecast dispersion (DISP) is on average 0.0091 (median value 0.0029$)$ and that analyst forecast error $(E R R O R)$ is on average 0.0612 (median value 0.0600). Sample firms are followed by, on average, 6 analysts (median value $5) .{ }^{15}$

\section{[INSERT TABLE 1 ABOUT HERE]}

Table 2 presents a correlation matrix. We note a significantly negative correlation between ( $\triangle$ )SIMSCORE and both DISP and ERROR (significant at the (10\%) $1 \%$ level). The correlation between ( $\triangle$ )SIMSCORE and ANALFOL is negative (significant at the $5 \%$ level). Correlations among the control variables are modest (all below 0.6) and are therefore not indicative of multicollinearity problems. The largest VIF equals 5.36 (Model IV in Table 3 and Model VIII in Table 4). We, therefore, conclude that our results are not materially affected by multicollinearity.

\section{[INSERT TABLE 2 ABOUT HERE]}

\subsection{Multivariate results}

Model I and Model II (Model III and Model IV) in Table 3 present results for estimating Equation 1 (with DISP as the dependent variable), based on SIMSCORE ( $\triangle$ SIMSCORE). In

\footnotetext{
15 Note that reported figures (in Table 1) for the analyst following (ANALFOL), are based on the natural logarithm of the number of analysts following the firm.
} 
Model I, SIMSCORE has a negative coefficient, which is significant at the $10 \%$ level. In the model including the interaction term between SIMSCORE and ABOVE (Model II), the positive coefficient on SIMSCORE is insignificant, while the interaction term (i.e., SIMSCORE $\times$ $A B O V E$ ) has a negative coefficient (significant at the 5\% level) with a magnitude considerably larger than the main effect. Moreover, the joint coefficient indicates that SG\&A similarity to the social benchmark has a significantly different effect on analyst forecast dispersion depending on whether a firm's SG\&A ratio exceeds or falls below the social benchmark. It suggests that higher similarity to the social benchmark reduces information asymmetry between firms and analysts and, therefore, attenuates analyst information uncertainty, but only for firms with a previous SG\&A ratio exceeding the social benchmark. These findings lend strong support to $H 4$ (and partial support to $H 1$ ).

Results based on $\triangle$ SIMSCORE are in line with those based on SIMSCORE and even more significant. To assess the economic significance of our main findings, we also estimated Equation 1 (specifically Model II and Model IV) based on standardised variables. Based on these standardised regressions (untabulated), the coefficient for SIMSCORE ( $\triangle$ SIMSCORE), for firms with an SG\&A ratio exceeding the social benchmark in the previous period, equals 1.2951 (-.8677). In other words, a one standard deviation increase in SIMSCORE ( $\triangle$ SIMSCORE) decreases DISP by 1.2951 (.8677) standard deviations for these firms. This finding indicates that the magnitude of the effect is non-trivial.

It is worth noting that results of estimating Model IV, excluding the interactions of earnings management and agency variables with $\triangle$ SIMSCORE (untabulated, but available upon request), are more significant and in line with $H 4$. This finding is consistent with the idea that deviations from the SG\&A social benchmark could be partially explained based on alternative scenarios (cf. supra).

Interestingly, the coefficient for $A B O V E$ is significantly positive (at the $1 \%$ level) in both Model II and Model IV. This observation is consistent with financial analysts having more dispersed beliefs about cost behaviour and future earnings of firms with an SG\&A ratio exceeding the social benchmark (i.e., higher information asymmetry). The positive coefficient for $A B O V E$ is in line with the view that an SG\&A ratio exceeding the social benchmark adds considerable doubt about the firm's ability to effectively control overhead expenses and efficiently allocate resources, feeding information asymmetry and increasing analyst information uncertainty. 
In general, coefficients for the control variables are stable across the different models and are in line with results from prior studies, except for HISTCOMP. Coefficients for HISTCOMP in the models based on SIMSCORE (i.e., Model I and Model II) are qualitatively different from those in the models based on $\triangle$ SIMSCORE (i.e., Model III and Model IV). Coefficients for HISTCOMP in the former models are insignificant. This observation supports the idea that ambiguity in SG\&A interpretations imperils the effect of historical performance feedback on analyst information uncertainty. However, in the latter models, the coefficient for HISTCOMP is significantly positive (at the $1 \%$ level). This observation is consistent with the idea that an SG\&A ratio exceeding the historical benchmark increases doubt about earnings implications of a firm's SG\&A behaviour.

\section{[INSERT TABLE 3 ABOUT HERE]}

Table 4 presents results for estimating Equation 2 (with ERROR as the dependent variable). Model V and Model VI (Model VII and Model VIII) present results based on SIMSCORE ( $\triangle$ SIMSCORE). The coefficient for SIMSCORE is insignificant in Model V. Also, in Model VI, coefficients for SIMSCORE and SIMSCORE $\times$ ABOVE are insignificant. Similar to Model V, the coefficient for $\triangle$ SIMSCORE in Model VII is insignificant. While the coefficient for $\triangle$ SIMSCORE in Model VIII is insignificant, the coefficient for $\triangle S I M S C O R E \times A B O V E$ is significantly negative (at the 5\% level) and the joint coefficient is significant at the $5 \%$ level.

Results of estimating Equation 2, using standardised variables (untabulated), show that, for firms with an SG\&A ratio exceeding the social benchmark in the previous period, a one standard deviation increase in $\triangle$ SIMSCORE is associated with a .0562 standard deviation decrease in ERROR. This finding indicates that even though $\triangle$ SIMSCORE has a statistically significant effect on ERROR, the magnitude of the effect is rather trivial (in contrast with the effect on $D I S P)$.

In sum, results presented in Table 4 do not support $H 2$, whereas results based on $\triangle$ SIMSCORE (Model VIII) lend strong support to H5.

In line with expectations, in both Model VI and VIII, $A B O V E$ has a significantly positive coefficient (at the 1\% level) which is consistent with an SG\&A ratio exceeding the social benchmark feeding information asymmetry between managers and analysts and increasing information uncertainty. The significantly positive coefficient for $A B O V E$ is consistent with social comparison feedback being cognitively simplified into a dichotomy of successful or 
failed performance, with failure (i.e., an SG\&A exceeding the social benchmark) aggravating analyst information uncertainty (increasing forecast error).

Again, coefficients for the control variables are stable across the different models and are in line with prior literature. HISTCOMP has a significantly positive coefficient in Model V and Model VI, suggesting that an increase in the SG\&A ratio adds to analyst information uncertainty and makes earnings prediction more difficult (in line with the traditional view that a lower SG\&A ratio is better).

\section{[INSERT TABLE 4 ABOUT HERE]}

Model IX and Model X (Model XI and Model XII) in Table 5 present results for estimating Equation 3 (with $A N A L F O L$ as the dependent variable), using lagged (current) SIMSCORE as the main independent variable. Consistent with $H 3$, we observe a negative relationship (significant at the 1\% level) between SIMSCORE and ANALFOL in both Model IX and Model XI. Model X and Model XII present results for estimating Equation 3 including the interaction between SIMSCORE and ABOVE. We observe that the coefficient for SIMSCORE in both models is no longer significant, but its interaction with $A B O V E$ has a significantly negative coefficient (at the 5\% level) with a magnitude considerably larger than the main effect. Moreover, the p-value of the joint coefficient is significant at the $1 \%$ level in both models. This finding indicates that SG\&A similarity has a significant effect (no effect) on analyst following for the subsample of firms having an SG\&A ratio exceeding (falling below) the social benchmark. This suggests that higher SG\&A similarity to the social benchmark reduces information asymmetry between firms and analysts (and therefore reduces analyst information uncertainty), but only for firms with a previous SG\&A ratio exceeding the social benchmark. These findings support $H 6$.

Results of estimating Equation 3 based on standardised variables (untabulated), show that, for firms with an SG\&A ratio exceeding the social benchmark in the previous period, lagged (current) SIMSCORE has a coefficient that equals -.0524 (-.0643). That is, a one standard deviation increase in lagged (current) SIMSCORE is associated with a .0524 (.0643) standard deviation decrease in $A N A L F O L$ (or the number of analysts following the firm decreases by 1.0443 (1.0545)). This finding indicates that the magnitude of the effect of SG\&A similarity on the number of analysts following the firm is non-trivial. 
$A B O V E$ has a significantly positive coefficient in Table 5, supporting behavioural theory arguments that the social benchmark may have a prominent dichotomizing normative effect on decision-making. Coefficients for the control variables are in line results from prior studies). HISTCOMP has a significantly negative coefficient (at the 5\% level) in Model IX and Model X. This observation is consistent with the idea that an increase in the SG\&A ratio adds to information asymmetry with regard to the effectiveness of overhead cost control, feeding analyst information uncertainty and thus negatively affecting analyst coverage.

\section{[INSERT TABLE 5 ABOUT HERE]}

\subsection{Additional analyses}

\subsubsection{Endogeneity}

Our findings might be affected by a simultaneity problem if a shock to the residual term affects both the dependent variable and some of the independent variables (creating an endogeneity problem). To check for the possible presence of endogeneity, we estimate a 2SLS regression for each of our models, using an instrumental variable approach (Lev and Sougiannis, 1996) and employing a Hausman test (see e.g., Wooldridge, 2002).

Finding exogenous and strong instruments to run the first-stage regression (i.e., to estimate SIMSCORE) is empirically difficult (or even impossible). Lewbel (1997) shows that higher order moments of an exogenous variable can be used as an instrument in a 2SLS estimation, when no other data is available. The use of higher order moments of an endogenous variable as instrument is customary in econometrics (Lewbel, 1997) and also suggested and used in prior studies (see e.g., Larcker, 2003, Banker et al., 2011). ${ }^{16}$ We therefore use the thirdorder moment of the potentially endogenous variable (i.e., SIMSCORE) as the instrument in the first-stage regression. In the first-stage, we regress the potentially endogenous variable on the instrument and the other control variables. To assess whether the instrument is strong enough, we look at the (partial) F-statistic of the first-stage model associated with the instrument, with a partial F-statistic larger than 10 indicating a strong instrument (Staiger and Stock, 1997). Next, we add the residual term obtained from the first-stage regression ( $r$ ) to the second-stage regression. A significant coefficient for the residual term then indicates an endogeneity problem.

\footnotetext{
${ }^{16}$ For further information, see Lewbel (1997).
} 
Model XIII (Model XIV) of Panel A of Table 6 shows results of testing the strength of lagged SIMSCORE ${ }^{3}\left(\operatorname{SIMSCORE}^{3}\right)$ as an instrument for lagged SIMSCORE (SIMSCORE). Based on Panel A, we note that partial F-statistics are substantially larger than the common threshold of 10 , confirming the strength of lagged SIMSCORE ${ }^{3}\left(\operatorname{SIMSCORE}^{3}\right)$ as an instrument.

Model XV (Model XVI) of Panel B of Table 6 presents results for the Hausman test of endogeneity for the forecast dispersion (error) model. As reported in Panel B of Table 6, $(r)$ is not statistically significant in any of the models, suggesting that there is no endogeneity problem and our OLS estimates in the forecast dispersion (error) model are thus robust.

Model XVII (Model XVIII) in Panel C of Table 6 presents results of the Hausman endogeneity test for the analyst following model, where the residual term from the first-stage regression is added into the second-stage regression (i.e., the model with $A N A L F O L$ as the dependent variable and lagged SIMSCORE (SIMSCORE) as the independent variable of primary interest). Based on Panel $\mathrm{C}$, we note that the coefficient for $(r)$ is not statistically significant in any of the models, suggesting that there is no endogeneity problem and our OLS estimates are thus robust. ${ }^{17}$

In sum, results reported in Table 6 suggest that our estimates based on OLS regressions are not biased due to an endogeneity problem. ${ }^{18}$

\section{[INSERT TABLE 6 ABOUT HERE]}

\subsubsection{Other analyses}

Anecdotal evidence suggests that managers are prone to overspend on SG\&A. In a similar vein, White and Dieckman (2005) document that SG\&A spending is heavily dependent on the gross profit margin, suggesting that 'companies appear to spend more if they have more to spend' (p. 23). Therefore, we also controlled for gross profit margin and it does not qualitatively affect our findings (untabulated, but available upon request).

\footnotetext{
${ }^{17}$ Results of 2SLS and the Hausman test of endogeneity, based on $\triangle S I M S C O R E$ (untabulated, but available upon request) are in line with the ones based on SIMSCORE.

${ }^{18}$ One may argue that given the lack of a strong instrument to be used in the first-stage regression model, the industry-average of the potentially endogenous variable (i.e., SIMSCORE) could be used as an instrument. According to Larcker (2003), factors affecting managerial intent and firms' cost behaviour such as production and revenue functions, growth opportunities and competition level, are likely to be similar across firms in the industry (Banker et al., 2011). The industry-average of the potentially endogenous variable is thus likely to exhibit similar endogeneity problems (Banker et al., 2011). Nevertheless, we also instrumented the potentially endogenous variable using the average within the industry (both including and excluding the focal firm) as the instrument in the first-stage regressions. The F-statistics associated with these instruments (partial F-statistics) were substantially lower than the threshold of 10, being indicative of weak instruments.
} 


\section{Discussion and conclusion}

Prior research indicates that (change in) SG\&A provides an ambiguous signal about a firm's future performance. Interpretational ambiguity of the SG\&A signal is likely to promote search for information-relevant external cues to assess reasonable expectations of a firm's SG\&A and to compare and evaluate its SG\&A ratio. Social comparison based on an industryspecific peer-based benchmark (or social benchmark) is argued to provide incremental common interpretation of reported SG\&A, reducing analyst information uncertainty with regard to the effectiveness in controlling SG\&A and efficiency in resource allocations. Our empirical results are generally consistent with these expectations.

Results of this study provide us with two important insights: (1) exceeding the social SG\&A benchmark increases information uncertainty and adds considerable doubt about the firm's ability to effectively control overhead expenses and efficiently allocate resources (indicated by the positive relationship between the dichotomy (ABOVE) and measures of analyst information uncertainty); and (2) for firms with an SG\&A ratio exceeding the social benchmark, higher similarity to the social benchmark has an uncertainty-decreasing effect, supporting the idea that social comparison feedback is normatively simplified into a dichotomy of successful (represented by an SG\&A below the social benchmark) or failed performance (represented by an SG\&A exceeding the social benchmark), with failure perceived by analysts as driving intended remedial action. These contingent findings lend strong support to the varying weights model of social comparison and suggest that social comparison is much less relevant to reduce analyst uncertainty for firms with an SG\&A ratio that falls below the social benchmark. Our results thus suggest that social comparison has a two-tier effect on financial analysts' assessment of firms' SG\&A ratio, with simple comparison of the SG\&A ratio against that of peers (i.e., based on the dichotomy) constituting the first stage and the assessment based on similarity to the benchmark (attainment discrepancy) coming into play in a second stage.

Our study has limitations offering fruitful avenues for further research. Firstly, we focus on reported SG\&A to study the relevance of social comparison for financial reporting, but other areas of cost behaviour and corporate disclosure in general may also be relevant in this regard. Key is that the reporting issues involved are subject to significant public exposure and are intrinsically ambiguous. Second, we focus on information processing by financial analysts. Other types of stakeholders (e.g., investors) also have to deal with ambiguities in interpreting SG\&A. As such, it might be interesting to explore the effect of (change in) SG\&A similarity 
on stock price performance. Third, while the way we select peer firms (based on industry and firm size) is based on prior academic literature, other ways of selecting peer firms may be used in practice. Testing our hypotheses using alternative peer determination approaches may be relevant for future research. Finally, we selected the third order moment of the potentially endogenous variable as an instrument to estimate the first-stage regressions. Finding other type(s) of strong exogenous instruments to estimate the first-stage regressions, to control for the endogeneity problem, could be an improvement to this type of research. 


\section{Appendix}

\section{A.1 Definition of variables}

DISP

ERROR

ANALFOL

SIMSCORE

$\triangle S I M S C O R E:$

HISTCOMP

INSTHLD

NUMAN

SIZE

SURPRISE
Analyst forecast dispersion, being the standard deviation of analyst forecasts of one-year ahead EPS at the end of month four after fiscal year-end date, scaled by stock price on the same day;

Analyst forecast error, being the absolute value of the difference between the average analyst forecast of one-year ahead EPS, at the beginning of month 8 before fiscal year-end date, and actual one-year ahead EPS, scaled by stock price on the day of the forecast;

Analyst following, being the natural logarithm of the number of analysts following the firm at the end of month four after fiscal year-end date;

SG\&A similarity score (see Section 3.2);

Change in similarity score, being $\operatorname{SIMSCORE}_{t}$ minus $\operatorname{SIMSCORE}_{t-1}$

Variable reflecting historical comparison, being SG\&A ratio in year $t$ minus SG\&A ratio in year $t-1$;

Institutional holdings, being the percentage of a firm's shares held by institutional investors at fiscal year-end date;

Natural logarithm of the number of analysts following the firm at fiscal year-end date;

Firm size, being the natural logarithm of total assets at fiscal year-end date ${ }^{19}$

Earnings surprise, being the absolute value of the relative change in earnings per share (EPS) at fiscal year-end date (i.e., $\left(\mathrm{EPS}_{\mathrm{t}}-\mathrm{EPS}_{\mathrm{t}}\right.$ 1)/EPS $\mathrm{EP}_{\mathrm{t}-1}{ }^{20}$

\footnotetext{
${ }^{19}$ Using natural logarithm of market value as a proxy for firm size does not materially change our results.

${ }^{20}$ Using lagged stock price at fiscal year-end date as a scalar yields qualitatively similar findings.
} 
Dummy variable that is coded one if the firm reports a loss in the current fiscal year; and zero otherwise;

LEV

VOLATILITY

SALES GROWTH

MTB

OPCOST

$R E M$

ACCR_RESID

BENCH

INFOQUAL
Leverage, being total debt scaled by total assets;

Volatility of return on assets (ROA), being the standard deviation of ROA over the last five years;

Growth in net sales, being the relative change in net sales at fiscal year-

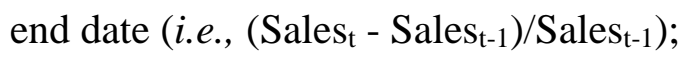

Market-to-book, being sum of market value of equity and book value of debt, scaled by total assets;

Operating expenses, being the sum of cost of sales and SG\&A expenses, scaled by net sales;

An indicator of real earnings management, being a dummy variable that is coded 1 if the residual of the SG\&A model suggested by Gunny (2010) (Equation 4) belongs to the bottom quartile; and zero otherwise (see Section A.2 in Appendix for detailed information about the calculation of this variable);

A measure of accruals management, being the residual of the model suggested by Dechow and Dichev (2002) (Equation 5) (see Section A.3 in Appendix for detailed information about the calculation of this variable);

Dummy variable capturing earnings management aimed at meeting earnings benchmarks. The variable is coded one if either a firm's relative net income (being net income scaled by total assets) or its relative change in net income (being change in net income divided by total assets) falls within the range $[0,0.01]$; and zero otherwise ${ }^{21}$

A measure of information quality, being the firm-specific standard deviation of residuals obtained from estimating Equation 5 over the past

\footnotetext{
${ }^{21}$ Consistent with Gunny (2010), we opted for .01 as a cut-off value. Employing alternative cut-off values, being .005 (consistent with Burgstahler and Dichev (1997)) and .02 (arbitrarily chosen), do not materially affect our results.
} 
three years (i.e., t-3 up to t-1) ${ }^{22}$ (see Section A.4 in Appendix for detailed information about the calculation of this variable);

$\operatorname{BigN}$

$O C F$

CEO_COMP

CEO_HOR

EXPERIENCE

Year

$i$ and $t$
Dummy variable that is coded 1 if the firm hires a BigN auditor ${ }^{23}$; and 0 otherwise;

Variable capturing managers' empire building incentives arising from the agency problem, being operating cash flow scaled by total assets;

Variable capturing managers' empire building incentives arising from the agency problem due to their compensation schemes, being sum of CEO salary and bonuses (both cash and non-cash) scaled by total CEO compensation;

Variable capturing managers' empire building incentives arising from the agency problem due to CEO horizon, being an indicator variable that is coded one if a change of CEO occurred in the current or next year; and zero otherwise;

Analyst experience, being mean of the number of years between analysts' first appearance in the I/B/E/S database and fiscal year-end date ${ }^{24}$

Year dummies;

Denote firms and years.

\footnotetext{
${ }^{22}$ Using a 5-year standard deviation of residuals (i.e., over year t-4 to year t) does not materially change our results.

${ }^{23}$ The BigN are: PricewaterhouseCoopers; Klynveld Peat Marwick Goerdeler; Deloitte; Ernst \& Young; and Arthur Andersen (for the observations of 2002). As a robustness check, we also excluded Arthur Andersen from the list of BigN audit firms (because of the Enron fraud in which Arthur Andersen was involved). Results, after elimination of Arthur Andersen from the list of BigN audit firms, are not materially different.

${ }^{24}$ This approach is consistent with prior research (see e.g., Yu, 2008, Harvey et al., 2011, De Franco et al., 2015).
} 


\section{A.2 Calculation of $\operatorname{REM}$ (a measure of real earnings management)}

Consistent with prior studies (e.g., Gunny 2010), we estimate the following equation (Equation 4) for every industry (on a yearly basis) with at least 15 observations:

$$
\frac{S G \& A_{i t}}{A_{i t-1}}=\alpha_{0}+\alpha_{1} \frac{1}{A_{i t-1}}+\alpha_{2} M V_{i t}+\alpha_{3} Q_{i t}+\alpha_{4} \frac{I N T_{i t}}{A_{i t-1}}+\alpha_{5} \frac{\Delta S A L E S_{i t}}{A_{i t-1}}+\alpha_{6} \frac{\Delta S A L E S_{i t}}{A_{i t-1}} \times D_{i t}+\varepsilon_{i t}
$$

Where,

$A$

$M V$

$Q$

INT

$\triangle S A L E S$

$D$

Total assets;

Market value of equity, being the natural logarithm of the product of common shares outstanding and the closing price on the last trading day in a year;

Tobin's Q, being the sum of market value of equity, preferred stock, current portion of long-term debts and long-term debt, scaled by lagged total assets;

Internal funds, being the sum of depreciation and amortisation, income before extraordinary items and research and development (R\&D) expenses, ${ }^{25}$

Change in net sales (i.e., Salest - Salest-1);

Dummy variable equal to 1 when total sales decrease between $t-1$ and $t$, zero otherwise. ${ }^{26}$

Note that Equation 4 estimates the normal level of SG\&A based on variables identified in prior studies (e.g., Gunny 2010) as drivers of a firm's real activities (such as SG\&A). Residuals of the estimated model therefore represent deviations from the expected level of SG\&A (or discretionary SG\&A). Firm-year observations with lower residuals are more likely to engage in real earnings management (i.e., managerial intent to increase earnings) (Gunny 2010). Consistent with Gunny (2010), we define a dummy variable (REM) that is coded 1 if the

\footnotetext{
25 Missing values of R\&D are replaced with zero. Eliminating the observations with missing value of R\&D expenses or dropping INT from equation 2 does not materially affect our results.

${ }^{26}$ Similar to Gunny (2010), we exclude D from Equation 4, because the corresponding VIF well exceeds the critical value of 10, giving rise to multicolinearity issues. Nevertheless, results based on estimating Equation 4 including D, are not materially different.
} 
residual attributed to a firm-year observation belongs to the bottom quartile of SG\&A residuals; and zero otherwise. We use REM as a proxy for real earnings management. 


\section{A.3 Calculation of $A C C R \_R E S I D$ (a measure of accruals management)}

In line with prior studies (Francis et al., 2004, Francis et al., 2005), we estimate the normal level of total working capital accruals, using the model suggested by Dechow and Dichev (2002) (i.e., Equation 5) ${ }^{27}$ to calculate our proxy for accruals management (all variables are scaled by average of beginning- and end-of-period total assets):

$$
T C A_{i t}=\beta_{0}+\beta_{1} C F O_{i t-1}+\beta_{2} C F O_{i t}+\beta_{3} C F O_{i t+1}+\beta_{4} \Delta S A L E S_{i t}+\beta_{5} P P E_{i t}+\gamma_{i t}
$$

Where,

$T C A$

Total working capital accruals, being change in current assets minus change in current liabilities minus change in cash plus change in debt in current liabilities;

CFO Cash flow from operations;

PPE Property, plant and equipment.

Residuals of this model represent deviations from the normal level of working capital accruals, providing a metric capturing accruals management (the larger the residual, the more likely that the firm engages in accruals management). We use the residual term obtained from Equation 5 (ACCR_RESID) in our model to proxy for accruals management.

\footnotetext{
27 Inspired by McNichols (2002), we add change in net sales ( $\triangle S A L E S$ ) and gross property, plant and equipment (PPE) as additional explanatory variables into Dechow and Dichev's (2002) model.
} 


\section{A.4 Calculation of INFOQUAL (a measure of firms' information environment quality)}

Based on prior literature (e.g., Francis et al., 2004, Francis et al., 2005), we add an additional control that captures firms' financial information quality, affecting the quality of their information environment. Specifically, we add the standard deviation of residuals obtained from Equation 5 (discretionary accruals) over a three-year period (i.e., year $\mathrm{t}-2$ up to year $\mathrm{t}$ ), into our model as a measure of information quality (INFOQUAL). We focus on a measure based on accruals because it is expected that firms' stakeholders, such as financial analysts, value a firm based on their assessment of financial performance, such as cash flow, in the future. Prior studies (e.g., Dechow, 1994) document current earnings (consisting of an accrual and a cash flow component) to effectively subsume information about future cash flows. However, the accrual component of current earnings is argued to be characterised by greater uncertainty than the cash flow component, because of being at managerial discretion (accruals are the product of judgements, estimates and allocations), while the cash flow component of earnings is realised (Francis et al., 2004). 
TABLE 1: Descriptive statistics

\begin{tabular}{|c|c|c|c|c|c|c|}
\hline & \multicolumn{3}{|c|}{ COMPUSTAT } & \multicolumn{3}{|c|}{ FINAL SAMPLE } \\
\hline & Median & Mean & Std Dev & Median & Mean & Std Dev \\
\hline Net sales (million USD) & 272.1365 & 2627.2660 & 12546.570 & 656.4050 & 3986.7150 & 12720.1000 \\
\hline SG\&A (million USD) & 59.9310 & 538.4307 & 2176.8570 & 137.2735 & 811.2956 & 2686.8090 \\
\hline SG\&A/Sales & .2545 & .3007 & .2057 & .2469 & .2878 & .1926 \\
\hline SG\&A/Total expenses & .2580 & .2630 & 6.1550 & .2589 & .3007 & .2527 \\
\hline Total assets (million USD) & 311.6665 & 3442.7350 & 14917.2200 & 751.5480 & 5075.1920 & 17972.7400 \\
\hline SIMSCORE & -.6857 & -.7905 & .5904 & -.6657 & -.7700 & .5714 \\
\hline$\triangle S I M S C O R E$ & .0001 & .0000 & .3956 & .0001 & -.0000 & .3944 \\
\hline$D I S P$ & & & & .0029 & .0091 & .0645 \\
\hline ERROR & & & & .0600 & .0612 & 1.1333 \\
\hline ANALFOL & & & & 1.6094 & 1.7281 & .8260 \\
\hline HISTCOMP & & & & .9864 & .9947 & .2379 \\
\hline INSTHLD & & & & .6375 & .5562 & .3158 \\
\hline$S I Z E$ & & & & 6.6221 & 6.7586 & 1.7803 \\
\hline SURPRISE & & & & .50000 & 1.9460 & 7.7056 \\
\hline LOSS & & & & .0000 & .2292 & .4203 \\
\hline$L E V$ & & & & .1561 & .1903 & .1907 \\
\hline VOLATILITY & & & & .0410 & .0902 & .3976 \\
\hline SALES GROWTH & & & & .0915 & .1281 & .3583 \\
\hline$M T B$ & & & & 1.5686 & 1.9521 & 1.2878 \\
\hline OPCOST & & & & .8621 & .8355 & .1526 \\
\hline$A C C R \_R E S I D$ & & & & -.0017 & .0019 & .3599 \\
\hline INFOQUAL & & & & .0761 & .1997 & .4201 \\
\hline$O C F$ & & & & .1081 & .1157 & .1012 \\
\hline CEO_COMP & & & & .3877 & .4070 & .2358 \\
\hline CEO_HOR & & & & .0000 & .1686 & .3744 \\
\hline EXPERIENCE & & & & 6.7166 & 6.8724 & 3.3009 \\
\hline
\end{tabular}

SIMSCORE a focal firm's SG\&A ratio minus the average SG\&A ratio within its industry-specific peer-based group, scaled by the standard deviation of SG\&A ratios within the peer group; $\triangle$ SIMSCORE change in SIMSCORE (i.e., SIMSCOREt - SIMSCOREt-1); DISP standard deviation of analyst forecasts of one-year ahead EPS at the end of month four after fiscal year-end date, scaled by stock price at the same date; ERROR absolute value of the difference between average analyst forecast of one-year ahead EPS, at the beginning of month 8 before fiscal year-end date, and actual one-year ahead EPS, scaled by stock price on the day of forecast; $A N A L F O L$ the natural logarithm of the number of analysts following the firm at the end of month four after fiscal year-end date; $H I S T C O M P$ historical comparison, being SG\&A ratio in year $t$ minus SG\&A ratio in year t-1; INSTHLD percentage of a firm's shares held by institutional investors; SIZE natural logarithm of total assets at fiscal year-end date; SURPRISE absolute value of the relative change in EPS at fiscal year-end date (i.e., (EPSt - EPSt-1)/EPSt-1); LOSS dummy variable that is coded one if the firm reports a loss in the current fiscal year, and zero otherwise; $L E V$ total debt scaled by total assets; VOLATILITY standard deviation of ROA over the last 5 years; SALES GROWTH growth in net sales at fiscal year-end date (i.e., (Salest - Salest-1)/Salest-1); MTB the sum of market value of equity and book value of debts, scaled by total assets; $O$ PCOST operating expenses, being the sum of cost of sales and SG\&A expenses, scaled by net sales; $A C C R \_R E S I D$ a measure of accruals management, being the residuals obtained from estimation of equation (3); INFOQUAL

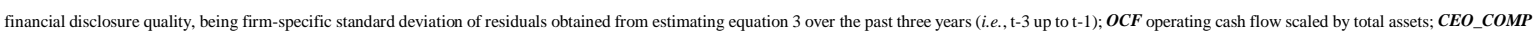


CEO compensation, being sum of salary and bonus (both cash and non-cash) scaled by total compensation; $C E O \_H O R$ CEO horizon, being an indicator variable that is coded one if a change of CEO occurred in the current or next year, and zero otherwise; EXPERIENCE analyst experience, being the number of years between when an analyst first appears in the I/B/E/S database and the fiscal year-end date. 
TABLE 2: Correlation matrix

\begin{tabular}{|c|c|c|c|c|c|c|c|c|c|c|c|c|c|c|c|c|c|c|c|c|c|c|c|c|c|}
\hline & & (I) & (2) & (3) & (4) & (5) & (6) & (7) & (8) & (9) & (10) & (II) & (12) & (13) & (14) & (15) & (16) & (17) & (18) & (19) & (20) & (21) & (22) & (23) & (24) \\
\hline (I) & DISP & 1.0000 & & & & & & & & & & & & & & & & & & & & & & & \\
\hline (2) & ERROR & $\begin{array}{l}.5936 \\
* * * *\end{array}$ & 1.0000 & & & & & & & & & & & & & & & & & & & & & & \\
\hline (3) & ANALFOL & $\begin{array}{l}-.1632 \\
* * * * \\
*\end{array}$ & $\begin{array}{l}-.2468 \\
* * *\end{array}$ & 1.0000 & & & & & & & & & & & & & & & & & & & & & \\
\hline (4) & SIMSCORE & $\begin{array}{l}-.0539 \\
* * * * *\end{array}$ & $\begin{array}{l}-.0631 \\
* * * *\end{array}$ & $\begin{array}{l}-.0191 \\
* * *\end{array}$ & 1.0000 & & & & & & & & & & & & & & & & & & & & \\
\hline (5) & 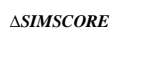 & $\begin{array}{l}-.0174 \\
*\end{array}$ & $\begin{array}{l}-.0167 \\
*\end{array}$ & $\begin{array}{l}-.0241 \\
* *\end{array}$ & $\begin{array}{l}.3039 \\
* * * *\end{array}$ & 1.0000 & & & & & & & & & & & & & & & & & & & \\
\hline (6) & НІІтсомР & $\begin{array}{l}.0589 \\
* * * * \\
*\end{array}$ & $\begin{array}{l}.1065 \\
* * *\end{array}$ & -0043 & $\begin{array}{l}-.0348 \\
* * * *\end{array}$ & $\begin{array}{l}.0305 \\
* * * *\end{array}$ & 1.0000 & & & & & & & & & & & & & & & & & & \\
\hline (7) & INSTHLD & $\begin{array}{l}-.1673 \\
* * *\end{array}$ & $\begin{array}{l}-.1541 \\
* * *\end{array}$ & $\begin{array}{l}.3017 \\
* * * *\end{array}$ & .0139 & -.0062 & .0158 & 1.0000 & & & & & & & & & & & & & & & & & \\
\hline (8) & SIZE & $\begin{array}{l}-.1115 \\
* * * *\end{array}$ & $\begin{array}{l}-1837 \\
* * *\end{array}$ & $\begin{array}{l}.5605 \\
* * * *\end{array}$ & $\begin{array}{l}.0190 \\
* * *\end{array}$ & $\begin{array}{l}-.0195 \\
* * \\
* *\end{array}$ & $\begin{array}{l}.0341 \\
* * * *\end{array}$ & $\begin{array}{l}.1134 \\
* * * *\end{array}$ & 1.0000 & & & & & & & & & & & & & & & & \\
\hline (9) & SURPRISE & .1887 & $\begin{array}{l}.1418 \\
* * *\end{array}$ & $\begin{array}{l}-.0651 \\
* * * *\end{array}$ & $\begin{array}{l}-.0336 \\
* * *\end{array}$ & $\begin{array}{l}-.0218 \\
* * *\end{array}$ & $\begin{array}{l}.0263 \\
* * *\end{array}$ & -0083 & $\begin{array}{l}-.0672 \\
* * * *\end{array}$ & 1.0000 & & & & & & & & & & & & & & & \\
\hline (10) & LosS & $\begin{array}{l}.4079 \\
* * * *\end{array}$ & $\begin{array}{l}.2946 \\
* * *\end{array}$ & $\begin{array}{l}-1602 \\
* * * *\end{array}$ & $\begin{array}{l}-.1151 \\
* * *\end{array}$ & $\begin{array}{l}-.0385 \\
* * * *\end{array}$ & $\begin{array}{l}.0965 \\
* * * *\end{array}$ & $\begin{array}{l}-.0812 \\
* * * *\end{array}$ & $\begin{array}{l}-1996 \\
* * * *\end{array}$ & $\begin{array}{l}.2084 \\
* * *\end{array}$ & 1.0000 & & & & & & & & & & & & & & \\
\hline (II) & LEV & $\begin{array}{l}.1795 \\
* * * *\end{array}$ & $\begin{array}{l}.0703 \\
* * * *\end{array}$ & $\begin{array}{l}.0482 \\
* * * *\end{array}$ & $\begin{array}{l}.0279 \\
* * * *\end{array}$ & .0108 & $\begin{array}{l}.0206 \\
* * *\end{array}$ & .0147 & $\begin{array}{l}.3288 \\
* * *\end{array}$ & $\begin{array}{l}.0453 \\
* * * *\end{array}$ & $\begin{array}{l}.0979 \\
* * * * \\
*\end{array}$ & 1.0000 & & & & & & & & & & & & & \\
\hline (12) & VOLATILITY & $\begin{array}{l}.2012 \\
* * *\end{array}$ & $\begin{array}{l}.2039 \\
* * *\end{array}$ & $\begin{array}{l}-11138 \\
* * * * \\
* *\end{array}$ & $\begin{array}{l}-.0474 \\
* * * *\end{array}$ & $\begin{array}{l}.0383 \\
* * * *\end{array}$ & $\begin{array}{l}.1233 \\
* * * *\end{array}$ & $\begin{array}{l}-.0841 \\
* * * *\end{array}$ & $\begin{array}{l}.0556 \\
* * * *\end{array}$ & $\begin{array}{l}.0556 \\
* * * *\end{array}$ & $\begin{array}{l}.1998 \\
* * * \\
* *\end{array}$ & $\begin{array}{l}-.0832 \\
* * * *\end{array}$ & 1.0000 & & & & & & & & & & & & \\
\hline (13) & SALES GROWTH & $\begin{array}{l}-.0828 \\
* * * *\end{array}$ & $\begin{array}{l}-.2146 \\
* * *\end{array}$ & $\begin{array}{l}.0750 \\
* * * *\end{array}$ & $\begin{array}{l}.0480 \\
* * * *\end{array}$ & $\begin{array}{l}.0933 \\
* * * *\end{array}$ & $\begin{array}{l}-.0176 \\
* \\
*\end{array}$ & $\begin{array}{l}.0174 \\
* \\
*\end{array}$ & $\begin{array}{l}-0.0177 \\
*\end{array}$ & .0023 & $\begin{array}{l}-.2046 \\
* * * * \\
* *\end{array}$ & $\begin{array}{l}-.0269 \\
* * * *\end{array}$ & $\begin{array}{l}.0663 \\
* * * *\end{array}$ & 1.0000 & & & & & & & & & & & \\
\hline (14) & MTB & $\begin{array}{l}.3746 \\
* * * *\end{array}$ & .2074 & $\begin{array}{l}.1650 \\
* * * *\end{array}$ & -.0006 & $\begin{array}{l}.0332 \\
* * *\end{array}$ & $\begin{array}{l}-.1312 \\
* * * *\end{array}$ & . 0137 & $\begin{array}{l}-.1616 \\
* * * *\end{array}$ & $\begin{array}{l}-.0783 \\
* * * *\end{array}$ & $\begin{array}{l}-.1665 \\
* * * *\end{array}$ & $\begin{array}{l}-.2236 \\
* * *\end{array}$ & $\begin{array}{l}.1795 \\
* * * *\end{array}$ & $\begin{array}{l}.2165 \\
* * * *\end{array}$ & 1.0000 & & & & & & & & & & \\
\hline (15) & OPCOST & $\begin{array}{l}.1330 \\
* * * *\end{array}$ & $\begin{array}{l}.1959 \\
* * *\end{array}$ & $\begin{array}{l}-3096 \\
* * * * \\
* * *\end{array}$ & $\begin{array}{l}-1083 \\
* * * *\end{array}$ & $\begin{array}{l}.0648 \\
* * * * \\
* *\end{array}$ & $\begin{array}{l}.0549 \\
* * * *\end{array}$ & $\begin{array}{l}-.0496 \\
* * * * \\
* *\end{array}$ & $\begin{array}{l}-3675 \\
* * * * \\
* *\end{array}$ & $\begin{array}{l}.0796 \\
* * *\end{array}$ & $\begin{array}{l}-.2677 \\
* * * * \\
*\end{array}$ & $\begin{array}{l}-2164 \\
* * * * \\
* * *\end{array}$ & $\begin{array}{l}-1641 \\
* * * * \\
* *\end{array}$ & $\begin{array}{l}-0922 \\
* * * * \\
* *\end{array}$ & $\begin{array}{l}-1081 \\
* * * * \\
* *\end{array}$ & 1.0000 & & & & & & & & & \\
\hline (16) & $R E M$ & $\begin{array}{l}.0181 \\
*\end{array}$ & -0032 & $\begin{array}{l}-0698 \\
. * * *\end{array}$ & $\begin{array}{l}-1104 \\
. * * *\end{array}$ & -0144 & $\begin{array}{l}-.0607 \\
* * * *\end{array}$ & $\begin{array}{l}-.0510 \\
* * * * \\
* * 4\end{array}$ & $\begin{array}{l}-1079 \\
* * * *\end{array}$ & -0028 & $\begin{array}{l}.0441 \\
* * * *\end{array}$ & $\begin{array}{l}.0523 \\
* * *\end{array}$ & $\begin{array}{l}.0279 \\
. * * *\end{array}$ & .1367 & $\begin{array}{l}.1001 \\
* * * *\end{array}$ & $\begin{array}{l}.1139 \\
. * * *\end{array}$ & 1.0000 & & & & & & & & \\
\hline (17) & ACCR_RESID & $\begin{array}{l}.0194 \\
* * * \\
* *\end{array}$ & $\begin{array}{l}.0211 \\
* *\end{array}$ & $\begin{array}{l}-.0336 \\
* * * *\end{array}$ & $\begin{array}{l}.0148 \\
* \\
*\end{array}$ & $\begin{array}{l}.0167 \\
* * * *\end{array}$ & .0013 & -0057 & .0097 & -.0062 & -.0049 & $\begin{array}{l}.0285 \\
* * * *\end{array}$ & $\begin{array}{l}-0175 \\
* * \\
* *\end{array}$ & $\begin{array}{l}-0998 \\
* * * \\
* * *\end{array}$ & $\begin{array}{l}-.0668 \\
* * * * \\
* * *\end{array}$ & .0164 & $\begin{array}{l}-0252 \\
* * * * \\
*\end{array}$ & 1.0000 & & & & & & & \\
\hline (18) & BENCH & $\begin{array}{l}-.0745 \\
* * * *\end{array}$ & $\begin{array}{l}.0437 \\
* * * *\end{array}$ & $\begin{array}{l}.0251 \\
* * * *\end{array}$ & .0056 & .0022 & . 0018 & $\begin{array}{l}.0325 \\
* * * *\end{array}$ & $\begin{array}{l}.1084 \\
* * *\end{array}$ & $\begin{array}{l}-.1431 \\
* * * *\end{array}$ & $\begin{array}{l}-.1722 \\
* * * *\end{array}$ & $\begin{array}{l}.0604 \\
* * * *\end{array}$ & $\begin{array}{l}-1006 \\
. * * * \\
* * *\end{array}$ & $\begin{array}{l}-.0203 \\
* * *\end{array}$ & $\begin{array}{l}-.0800 \\
-. * * \\
* * *\end{array}$ & $\begin{array}{l}-.0216 \\
* * *\end{array}$ & -.0012 & -0038 & 1.0000 & & & & & & \\
\hline (19) & INFOQUAL & $\begin{array}{l}.0629 \\
* * * *\end{array}$ & $\begin{array}{l}.0729 \\
* * * *\end{array}$ & $\begin{array}{l}-0404 \\
* * * *\end{array}$ & $\begin{array}{l}-.0326 \\
* * * *\end{array}$ & .0054 & -.0082 & $\begin{array}{l}-.0462 \\
* * * *\end{array}$ & $\begin{array}{l}-0418 \\
* * * *\end{array}$ & $\begin{array}{l}.0182 \\
* * *\end{array}$ & $\begin{array}{l}.0241 \\
* * * *\end{array}$ & $\begin{array}{l}-0.168 \\
* * * \\
* *\end{array}$ & $\begin{array}{l}.1353 \\
* * * *\end{array}$ & $\begin{array}{l}.0157 \\
*\end{array}$ & $\begin{array}{l}.0468 \\
* * * \\
*\end{array}$ & $\begin{array}{l}-.0306 \\
* * * *\end{array}$ & $\begin{array}{l}.0151 \\
* * * *\end{array}$ & $\begin{array}{l}.0565 \\
* * * *\end{array}$ & $\begin{array}{l}-.0325 \\
* * * *\end{array}$ & 1.0000 & & & & & \\
\hline (20) & BigN & $\begin{array}{l}-.1044 \\
* * * *\end{array}$ & $\begin{array}{l}-.0774 \\
* * * *\end{array}$ & $\begin{array}{l}.2450 \\
* * * *\end{array}$ & -0158 & -.0202 & .0464 .04 & $\begin{array}{l}.1713 \\
* * *\end{array}$ & $\begin{array}{l}.3749 \\
* * * *\end{array}$ & -.0029 & $\begin{array}{l}-.0791 \\
* * * *\end{array}$ & $\begin{array}{l}.0974 \\
* * * *\end{array}$ & $\begin{array}{l}-1368 \\
* * * *\end{array}$ & $\begin{array}{l}-.0616 \\
* * * *\end{array}$ & $\begin{array}{l}-0483 \\
* * * *\end{array}$ & $\begin{array}{l}-0892 \\
* * * * \\
* * *\end{array}$ & $\begin{array}{l}-.0715 \\
* * * *\end{array}$ & $\begin{array}{l}.0227 \\
* * *\end{array}$ & . 0127 & $\begin{array}{l}-.0860 \\
* * * *\end{array}$ & 1.0000 & & & & \\
\hline (21) & OCF & $\begin{array}{l}.2078 \\
* * * *\end{array}$ & $\begin{array}{l}-.2515 \\
* * *\end{array}$ & $\begin{array}{l}.2307 \\
* * * *\end{array}$ & .1131 & $\begin{array}{l}.0316 \\
* * * *\end{array}$ & $\begin{array}{l}-1064 \\
* * * * \\
* *\end{array}$ & $\begin{array}{l}.0522 \\
* * * \\
* * *\end{array}$ & $\begin{array}{l}.1523 \\
* * *\end{array}$ & $\begin{array}{l}-.0878 \\
* * *\end{array}$ & $\begin{array}{l}-.4227 \\
* * * *\end{array}$ & $\begin{array}{l}-.0806 \\
* * * \\
* *\end{array}$ & $\begin{array}{l}.0831 \\
* * * * *\end{array}$ & .2361 & .3967 & $\begin{array}{l}-5848 \\
.4 * *\end{array}$ & .0625 & -.0637 & $\begin{array}{l}-.0502 \\
. * * * *\end{array}$ & .0491 & . .0480 & 1.0000 & & & \\
\hline (22) & CEO_COMP & $\begin{array}{l}.0258 \\
* * * * \\
*\end{array}$ & .0238 & $\begin{array}{l}-3363 \\
* * *\end{array}$ & .0021 & .0094 & -.0137 & $\begin{array}{l}.0843 \\
* * * \\
*\end{array}$ & $\begin{array}{l}.4432 \\
* * * \\
*\end{array}$ & .0286 & $\begin{array}{l}.1070 \\
* * * *\end{array}$ & *.1123 & .1060 & -0133 & -0092 & . 1719 & $\begin{array}{l}.0779 \\
* * * \\
*\end{array}$ & $\begin{array}{l}.0186 \\
*\end{array}$ & $\begin{array}{l}.0296 \\
* * * \\
*\end{array}$ & -0152 & $\begin{array}{l}.1689 \\
* * *\end{array}$ & $\begin{array}{l}-.0984 \\
* * * * \\
* * *\end{array}$ & 1.0000 & & \\
\hline (23) & CEO_HOR & .0085 & $\begin{array}{l}.0520 \\
* * * *\end{array}$ & $\begin{array}{l}.0643 \\
* * * *\end{array}$ & -.0020 & -0133 & .0100 & $\begin{array}{l}.0769 \\
* * * *\end{array}$ & $\begin{array}{l}.0501 \\
* * * *\end{array}$ & -.0041 & -.0107 & -.0028 & .0010 & $\begin{array}{l}-.0351 \\
* * * *\end{array}$ & -0013 & .0079 & -0055 & .0027 & -.0100 & -.0009 & $\begin{array}{l}.0240 \\
* * *\end{array}$ & -.0017 & $\begin{array}{l}.0564 \\
* * * *\end{array}$ & 1.0000 & \\
\hline (24) & EXPERIENCE & $\begin{array}{l}-.0562 \\
* * * * \\
* * 4\end{array}$ & $\begin{array}{l}-.0431 \\
* * *\end{array}$ & $\begin{array}{l}.1205 \\
* * * *\end{array}$ & .0063 & -0082 & $\begin{array}{l}.0350 \\
{ }_{* * * *}\end{array}$ & $\begin{array}{l}.1931 \\
* * * *\end{array}$ & $\begin{array}{l}.1358 \\
* * * *\end{array}$ & $\begin{array}{l}-.0179 \\
* * *\end{array}$ & $\begin{array}{l}-.0263 \\
* * * * \\
* * 2\end{array}$ & $\begin{array}{l}.0676 \\
{ }_{* * * *}\end{array}$ & $\begin{array}{l}-1098 \\
* * * *\end{array}$ & $\begin{array}{l}-0888 \\
* * * * \\
* * *\end{array}$ & $\begin{array}{l}-.0834 \\
* * * *\end{array}$ & $\begin{array}{l}.0270 \\
{ }_{* * * *}\end{array}$ & $\begin{array}{l}.0102 \\
* * 2\end{array}$ & .0008 & 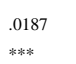 & $\begin{array}{l}-0198 \\
* * * * \\
* * *\end{array}$ & $\begin{array}{l}.0676 \\
* * * *\end{array}$ & $\begin{array}{l}-.0203 \\
* * *\end{array}$ & $\begin{array}{l}-.0728 \\
* * * *\end{array}$ & $\begin{array}{l}.0182 \\
*\end{array}$ & 1.0000 \\
\hline
\end{tabular}




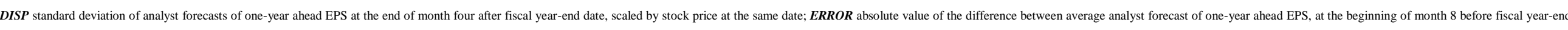

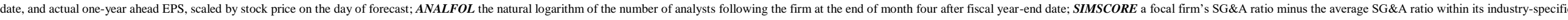

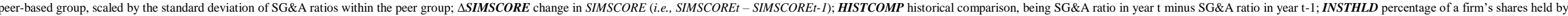

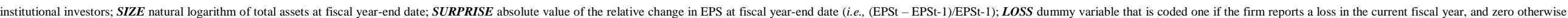

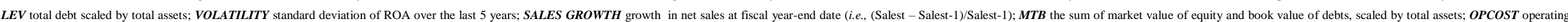

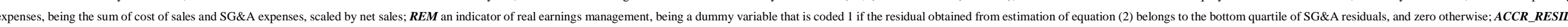

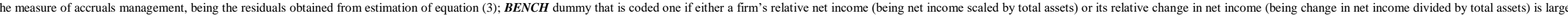

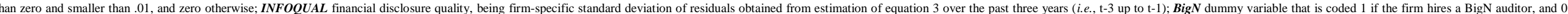

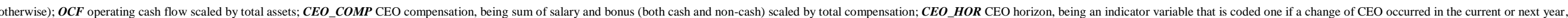
and zero otherwise; EXPERIENCE analyst experience, being the number of years between when an analyst first appears in the I/B/E/S database and the fiscal year-end date.

Significance at $.10(*), .05(* *)$ and $.01(* * *)$ levels. 
TABLE 3: Results for testing the relationship between SG\&A similarity and analyst forecast dispersion

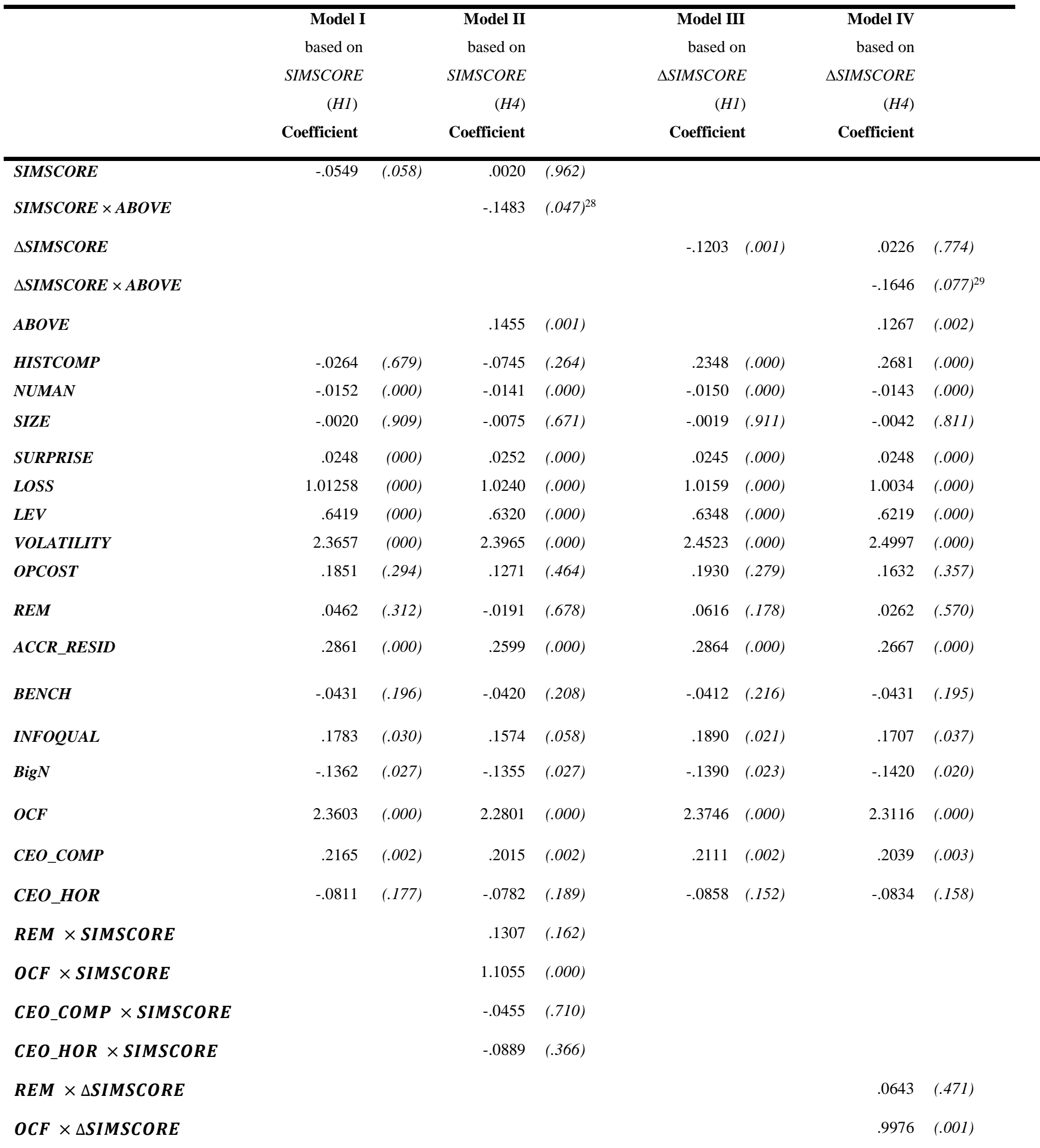

\footnotetext{
${ }^{28}$ The p-value of the joint coefficient equals .024 (i.e., significant at the $5 \%$ level)
}

${ }^{29}$ The p-value of the joint coefficient equals .007 (i.e., significant at the $1 \%$ level). 
YEAR

Max VIF Included

Included

$\mathrm{R}^{2}$
Included

2.20

9,022
Included

5.36

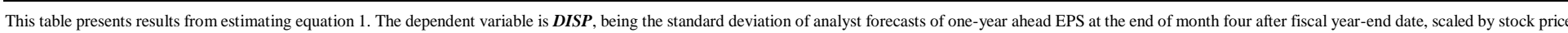
at the same date.

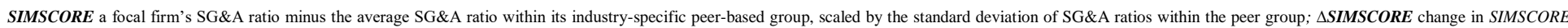

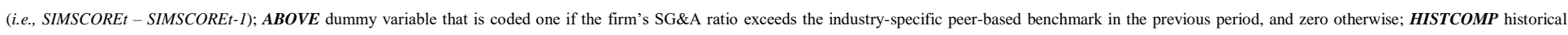

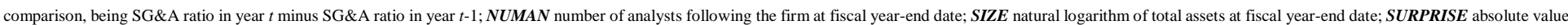

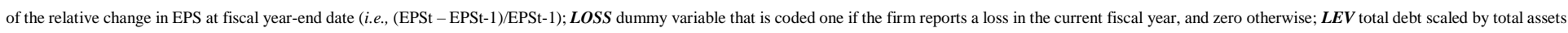

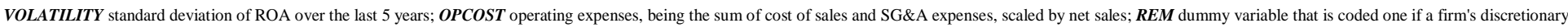

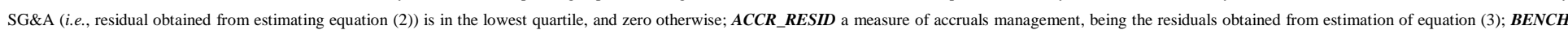

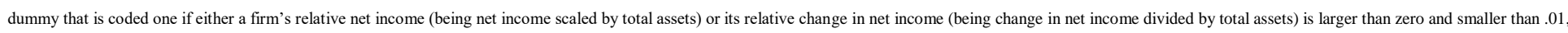

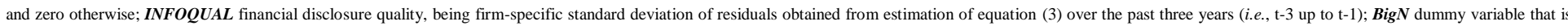

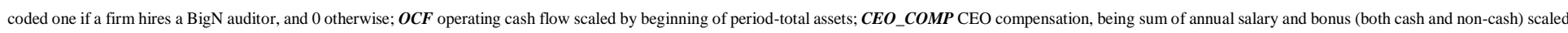

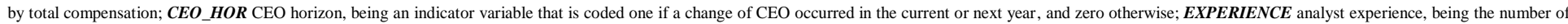
years between when an analyst first appears in the I/B/E/S database and the fiscal year-end date.

Numbers in parentheses represent p-values. 
YEAR

Max VIF

$\mathrm{R}^{2}$
Included
Included

3.77
Included
Included

5.36

6,939

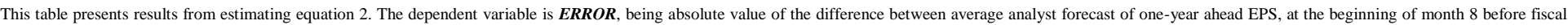
year-end date, and actual one-year ahead EPS, scaled by stock price on the day of forecast.

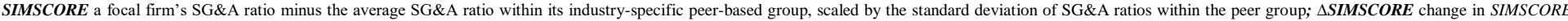

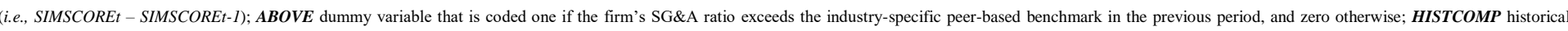

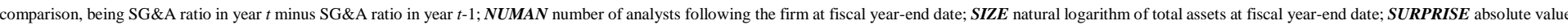

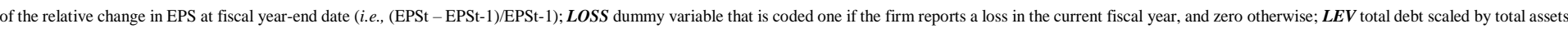

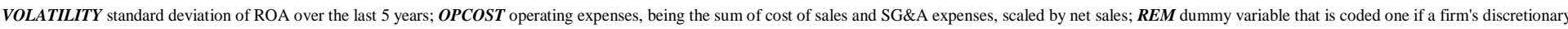

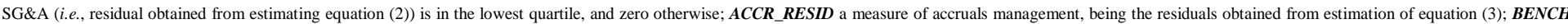

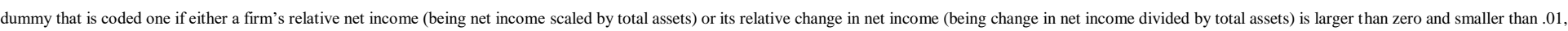

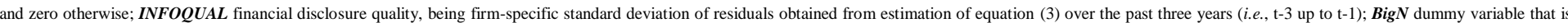

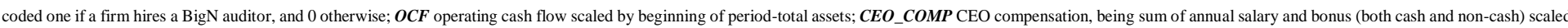

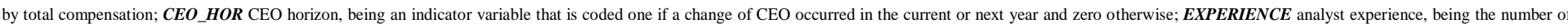
years between when an analyst first appears in the I/B/E/S database and the fiscal year-end date.

Numbers in parentheses represent p-values. 
TABLE 5: Regression results for testing the relationship between SG\&A similarity and analyst following

\begin{tabular}{|c|c|c|c|c|c|c|c|c|}
\hline & Model IX & & \multicolumn{2}{|l|}{ Model X } & \multicolumn{2}{|l|}{ Model XI } & \multicolumn{2}{|l|}{ Model XII } \\
\hline & Based on & & Based on & & Based on & & Based on & \\
\hline & lagged & & lagged & & current & & current & \\
\hline & SIMSCORE & & SIMSCORE & & SIMSCORE & & SIMSCORE & \\
\hline & $(H 3)$ & & $(H 6)$ & & $(H 3)$ & & $(H 6)$ & \\
\hline & Coefficient & & Coefficient & & Coefficient & & Coefficient & \\
\hline SIMSCORE & -.0570 & $(.006)$ & .0076 & $(.826)$ & -.0708 & $(.001)$ & .0163 & $(.644)$ \\
\hline SIMSCORE $\times$ ABOVE & & & -.0833 & $(.049)^{31}$ & & & -.1093 & $(.011)^{32}$ \\
\hline ABOVE & & & .0428 & $(.091)$ & & & .0632 & $(.014)$ \\
\hline НISTCOMP & -.4591 & $(.017)$ & -.5008 & $(.011)$ & -.0473 & $(.806)$ & .0285 & $(.884)$ \\
\hline INSTHLD & .7804 & $(.000)$ & .7785 & $(.000)$ & .7795 & $(.000)$ & .7768 & $(.000)$ \\
\hline SIZE & .2409 & $(.000)$ & .2422 & $(.000)$ & .2406 & $(.000)$ & .2428 & $(.000)$ \\
\hline SURPRISE & -.0018 & $(.216)$ & -.0018 & $(.222)$ & -.0019 & $(.179)$ & -.0020 & $(.152)$ \\
\hline LOSS & -.1148 & $(.000)$ & -.1059 & $(.000)$ & -.1111 & $(.000)$ & -.0978 & $(.000)$ \\
\hline$L E V$ & -.3856 & $(.000)$ & -.3832 & $(.000)$ & -.3799 & $(.000)$ & -.3719 & $(.000)$ \\
\hline VOLATILITY & -.4776 & $(.000)$ & -.4567 & $(.000)$ & -.4917 & $(.000)$ & -.4678 & $(.000)$ \\
\hline SALES GROWTH & .2176 & $(.000)$ & .2032 & $(.000)$ & .2294 & $(.000)$ & .2309 & $(.000)$ \\
\hline MTB & .1745 & $(.000)$ & .1672 & $(.000)$ & .1746 & $(.000)$ & .1656 & $(.000)$ \\
\hline OPCOST & -.5675 & $(.000)$ & -.5504 & $(.000)$ & -.5605 & $(.000)$ & -.5234 & $(.000)$ \\
\hline REM & -.0450 & $(.091)$ & -.0093 & $(.731)$ & -.0486 & $(.069)$ & .0000 & $(.000)$ \\
\hline$A C C R \_R E S I D$ & -.0479 & $(.162)$ & -.0426 & $(.211)$ & -.0471 & $(.170)$ & -.0380 & $(.263)$ \\
\hline BENCH & .0006 & $(.975)$ & -.0004 & $(.982)$ & .0009 & $(.965)$ & -.0005 & $(.981)$ \\
\hline INFOQUAL & -.1665 & $(.001)$ & -.1588 & $(.001)$ & -.1675 & $(.001)$ & -.1618 & $(.001)$ \\
\hline $\operatorname{BigN}$ & .0613 & $(.041)$ & .0571 & $(.055)$ & .0604 & $(.044)$ & .0536 & $(.070)$ \\
\hline$O C F$ & .0535 & $(.640)$ & .0994 & $(.381)$ & .0747 & $(.518)$ & .1295 & $(.257)$ \\
\hline CEO_COMP & -.2368 & $(.000)$ & -.2319 & $(.000)$ & -.2363 & $(.000)$ & -.2292 & $(.000)$ \\
\hline CEO_HOR & .0496 & $(.153)$ & .0510 & $(.142)$ & .0484 & $(.162)$ & .0467 & $(.177)$ \\
\hline$R E M \times S I M S C O R E$ & & & -.0010 & $(.984)$ & & & -.0137 & $(.789)$ \\
\hline$O C F \times S I M S C O R E$ & & & .3807 & $(.026)$ & & & .3587 & $(.037)$ \\
\hline CEO_COMP $\times$ SIMSCORE & & & .0270 & $(.681)$ & & & .0212 & $(.751)$ \\
\hline CEO_HOR $\times$ SIMSCORE & & & .0039 & $(.947)$ & & & .0836 & $(.214)$ \\
\hline EXPERIENCE & .0086 & $(.042)$ & .0089 & $(.034)$ & .0084 & $(.044)$ & .0089 & $(.034)$ \\
\hline YEAR & Included & & Included & & Included & & Included & \\
\hline Max VIF & 2.33 & & 3.73 & & 2.33 & & 3.87 & \\
\hline $\mathrm{R}^{2}$ & .5024 & & .5041 & & .5030 & & .5055 & \\
\hline
\end{tabular}

\footnotetext{
${ }^{31}$ The p-value of the joint coefficient equals .004 (i.e., significant at the $1 \%$ level).

${ }^{32}$ The p-value of the joint coefficient equals .000 (i.e., significant at the $1 \%$ level).
} 
SIMSCORE a focal firm's SG\&A ratio minus the average SG\&A ratio within its industry-specific peer-based group, scaled by the standard deviation of SG\&A ratios within the peer group; $A B O V E$ dummy variable that is coded one if the firm's SG\&A ratio exceeds the industry-specific peer-based benchmark in the previous period (and zero otherwise); HISTCOMP historical comparison, being SG\&A ratio in year $t$ minus SG\&A ratio in year $t$-1; INSTHLD percentage of a firm's shares held by institutional investors; SIZE natural logarithm of total assets at fiscal year-end date; SURPRISE absolute value of the relative change in EPS at fiscal yearend date (i.e., (EPSt - EPSt-1)/EPSt-1); LOSS dummy variable that is coded one if the firm reports a loss in the current fiscal year, and zero otherwise; $\boldsymbol{L E V}$ total debt scaled by total assets; VOLATILITY standard deviation of ROA over the last 5 years; SALES GROWTH growth in net sales at fiscal year-end date (i.e., (Salest - Salest-1)/Salest-1); MTB the sum of market value of equity and book value of debts, scaled by total assets; $\boldsymbol{O P C O S T}$ operating expenses, being the sum of cost of sales and SG\&A expenses, scaled by net sales; $\boldsymbol{R E M}$ dummy variable that is coded one if a firm's discretionary SG\&A (i.e., residual obtained from estimating equation (2)) is in the lowest quartile, and zero otherwise; $\boldsymbol{A C C R} \_$RESID a measure of accruals management, being the residuals obtained from estimation of equation (3); $\boldsymbol{B E N C H}$ dummy that is coded one if either a firm's relative net income (being net income scaled by total assets) or its relative change in net income (being change in net income divided by total assets) is larger than zero and smaller than .01, and zero otherwise; INFOQUAL financial disclosure quality, being firm-specific standard deviation of residuals obtained from estimation of equation (3) over the past three years (i.e., t-3 up to t-1); BigN dummy variable that is coded one if a firm hires a BigN auditor, and 0 otherwise; $\boldsymbol{O C F}$ operating cash flow scaled by beginning of period-total assets; $\boldsymbol{C E O}$ _COMP CEO compensation, being sum of annual salary and bonus (both cash and non-cash) scaled by total compensation; CEO_HOR CEO horizon, being an indicator variable that is coded one if a change of CEO occurred in the current or next year, and zero otherwise; EXPERIENCE analyst experience, being the number of years between when an analyst first appears in the I/B/E/S database and the fiscal year-end date. Numbers in parentheses represent p-values. 
TABLE 6: Endogeneity analyses

Panel A. Results of testing the strength of the third-order moment of (lagged) SIMSCORE as an instrument based on the first-stage regression

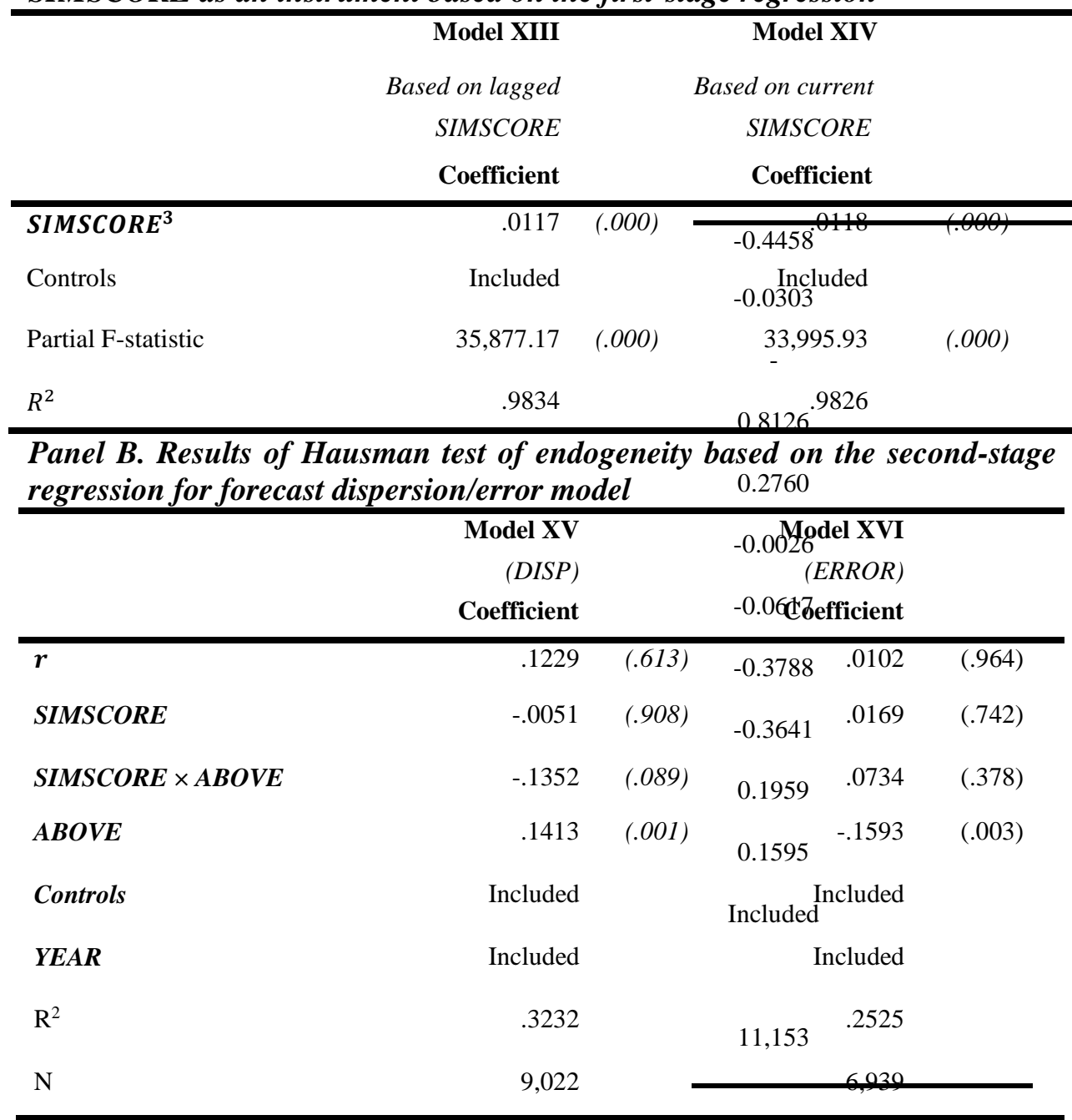

Panel C. Results of Hausman test of endogeneity based on the second-stage regression for the analyst following model

\begin{tabular}{|c|c|c|c|c|}
\hline & $\begin{array}{r}\text { Model XVII } \\
\text { Based on } \\
\text { lagged } \\
\text { SIMSCORE } \\
\text { Coefficient }\end{array}$ & & $\begin{array}{r}\text { Model XVIII } \\
\text { Based on } \\
\text { current } \\
\text { SIMSCORE } \\
\text { Coefficient }\end{array}$ & \\
\hline$r$ & .0698 & $(.449)$ & -.0970 & $(.273)$ \\
\hline SIMSCORE & .0108 & $(.597)$ & .0077 & $(.703)$ \\
\hline SIMSCORE $\times$ ABOVE & -.0904 & $(.001)$ & -.1040 & $(.000)$ \\
\hline ABOVE & .0452 & $(.002)$ & .0607 & $(.000)$ \\
\hline Controls & Included & & Included & \\
\hline$Y E A R$ & Included & & Included & \\
\hline $\mathrm{R}^{2}$ & .5041 & & .5048 & \\
\hline $\mathrm{N}$ & 8,916 & & 8,916 & \\
\hline
\end{tabular}




\section{References}

Abarbanell, J.S. \& Bushee, B.J., 1998. Abnormal Returns to a Fundamental Analysis Strategy. The Accounting Review, 73, 19-45.

Ahn, H.-J. \& Cai, J., 2005. Adverse selection, brokerage coverage, and trading activity on the Tokyo Stock Exchange. Journal of Banking and Finance, 29, 1483-1508.

Albuquerque, A., 2009. Peer firms in relative performance evaluation. Journal of Accounting and Economics, 48, 69-89.

Anderson, M., Banker, R., Huang, R. \& Janakiraman, S., 2007. Cost Behavior and Fundamental Analysis of SG\&A Costs. Journal of Accounting, Auditing \& Finance, 22, 1-28.

Anderson, M.C., Banker, R.D. \& Janakiraman, S.N., 2003. Are Selling, General, and Administrative Costs "Sticky"? Journal of Accounting Research, 41, 47-63.

Banker, R.D., Chen, J.Y.S. \& Park, H.-U., 2014. Cost behavior models analysts and investors use. Working paper Available at SSRN: http://ssrn.com/abstract=2482723.

Banker, R., Huang, R. \& Natarajan, R., 2011. Equity incentives and long-term value created by SG\&A expenditure. Contemporary accounting research, 71, 443-465.

Barron, O.E., Kim, O., Lim, S.C. \& Stevens, D.E., 1998. Using Analysts' Forecasts to Measure Properties of Analysts' Information Environment. The Accounting review, 73, 421-433.

Barry, C. \& Jennings, R., 1992. Information and diversity of analyst opinion. Journal of Financial and Quantitative Analysis, 27, 169-183.

Barth, M.E., Ron, K. \& Mcnichols, M.F., 2001. Analyst Coverage and Intangible Assets. Journal of Accounting Research, 39, 1-34.

Baumgarten, D., Bonenkamp, U. \& Homburg, C., 2010. The information content of the SG\&A ratio. Journal of Management Accounting Research, 22, 1-22.

Bhushan, R., 1989. Firm characteristics and analyst following. Journal of Accounting and Economics, 11, 255-274.

Bizjak, J.M., Lemmon, M.M. \& Naveen, L., 2008. Does the use of peer groups contribute to higher pay and less efficient compensation? Journal of Financial Economics, 90, 152168.

Black, D., Dikolli, S. \& Hofmann, C., 2011. Peer group composition, peer performance aggregation, and detecting relative performance evaluation. Workig Paper. Available at: http://papers.ssrn.com/sol3/papers.cfm?abstract_id=1910846.

Bromiley, P., 1991. Testing a causal model of corporate risk taking and performance. Academy of Management Journal, 34, 37-59.

Burgstahler, D. \& Dichev, I., 1997. Earnings management to avoid earnings decreases and losses. Journal of Accounting and Economics, 24, 99-126.

Cassell, C.A., Myers, L.A. \& Seidel, T.A., 2015. Disclosure transparency about activity in valuation allowance and reserve accounts and accruals-based earnings management. Accounting, Organizations and Society, 46, 23-38.

Chalmers, K. \& Godfrey, J.M., 2004. Reputation costs: the impetus for voluntary derivative financial instrument reporting. Accounting, Organizations and Society, 29, 95-125.

Chen, C.X., Lu, H. \& Sougiannis, T., 2012. The Agency Problem, Corporate Governance, and the Asymmetrical Behavior of Selling, General, and Administrative Costs. Contemporary Accounting Research, 29, 252-282.

Chen, L.H., Krishnan, J. \& Sami, H., 2015. Goodwill impairment charges and analyst forecast properties. Accounting Horizons, 29, 141-169.

Cialdini, R.B., 1993. Influence: The psychology of persuasion: Quill/William Morrow.

Ciccone, S.J., 2005. Trends in analyst earnings forecast properties. Internationa Review of Financial Analysis, 14, 1-22. 
Cyert, R.M. \& March, J.G., 1963. A behavioral theory of the firm: Oxford: Blackwell.

Cyert, R.M. \& March, J.G., 1992. A behavioral theory of the firm, 2nd ed.: Cambridge, MA: Blackwell.

Dacin, M.T., 1997. Isomorphism In Context: The Power And Prescription Of Institutional Norms. Academy of Management Journal, 40, 46-81.

De Franco, G., Hope, O.-K. \& Larocque, S., 2012. Analysts' choice of peer companies. Review of Accounting Studies, 20, 82-109.

De Franco, G., Hope, O.-K., Vyas, D. \& Zhou, Y., 2015. Analyst Report Readability. Contemporary Accounting Research, 32, 76-104.

Dechow, P.M., 1994. Accounting earnings and cash flows as measures of firm performance: The role of accounting accruals. Journal of Accounting and Economics, 18, 3-42.

Dechow, P.M. \& Dichev, I.D., 2002. The Quality of Accruals and Earnings: The Role of Accrual Estimation Errors. The Accounting Review, 77, 35-59.

Deephouse, D.L., 1996. Does isomorphism legitimate? Academy of Management Journal, 39, 1024-1039.

Deloitte, 2004. SG\&A cost reduction. Six steps to sustainability. Sydney: Deloitte Touche Tohmatsu Ltd-Sydney: Deloitte Touche Tohmatsu Ltd.

Dimaggio, P.J. \& Powell, W.W., 1983. The Iron Cage Revisited: Institutional Isomorphism and Collective Rationality in Organizational Fields. American Sociological Review, 48, 147160.

Dye, R.A. \& Sridhar, S.S., 1995. Industry-Wide Disclosure Dynamics. Journal of Accounting Research, 33, 175-194.

Ecker, F., Francis, J., Olsson, P. \& Schipper, K., 2011. Peer firm selection for discretionary accruals models. Working paper. Available at: http://152.19.224.144/Accounting/Documents/2011\%20GIA\%20Conference/Peer\%20 Firm\%20Selection\%20for\%20Discretionary\%20Accruals\%20Models-Schipper.pdf.

Ely, K.M., 1991. Inter-industry differences in relation between compensation and firm performance variables. Journal of Accounting Research, 29, 37-58.

Finkelstein, S. \& Hambrick, D.C., 1990. Top-management-team tenure and organizational outcomes: The moderating role of managerial discretion. Administrative Science Quarterly, 35, 484-503.

Fogarty, T.J. \& Rogers, R.K., 2005. Financial Analysts' reports: an extended institutional theory evaluation. Accounting, Organization and Siciety, 30, 331-356.

Foster, G., 1981. Intra-industry information transfers associated with earnings releases. Journal of Accounting and Economics, 3, 201-232.

Francis, J., Lafond, R., Olsson, P. \& Schipper, K., 2005. The market pricing of accruals quality. Journal of Accounting and Economics, 39, 295-327.

Francis, J., Lafond, R., Olsson, P.M. \& Schipper, K., 2004. Costs of Equity and Earnings Attributes. The Accounting Review, 79, 967-1010.

Gleason, C.A., Jenkins, N.T. \& Johnson, W.B., 2008. The contagion effects of accounting restatements. The Accounting Review, 83, 83-110.

Gong, G., Li, L.Y. \& Shin, J.Y., 2011. Relative performance evaluation and related peer groups in executive compensation contracts. The Accountngi Review, 86, 1007-1043.

Greve, H.R., 2008. A behavioral theory of firm growth: Sequential attention to size and performance goals. Academy of Management Journal, 51, 476-494.

Gunny, K.A., 2010. The Relation Between Earnings Management Using Real Activities Manipulation and Future Performance: Evidence from Meeting Earnings Benchmarks. Contemporary Accounting Research, 27, 855-888.

Hanlon, M., Rajgopal, S. \& Shevlin, T., 2003. Are executive stock options associated with future earnings? Journal of Accounting and Economics, 36, 3-43. 
Harvey, C.R., Mohammed, K. \& Rattray, S., 2011. Do analyst experience, location and gender affect the performance of broker recommendations in Europe? Working Paper available at: http://dx.doi.org/10.2139/ssrn.1850672.

Haunschild, P.R., 1993. Interorganizational imitation: The impact of interlocks on corporate acquisitions activity. Administrative Science Quarterly, 38, 564-592.

Healy, P.M. \& Palepu, K.G., 2001. Information asymmetry, corporate disclosure, and the capital markets: A review of the empirical disclosure literature. Journal of Accounting and Economics, 31, 405-440.

Hope, O.-K. \& Zhao, W., 2017. Market Reactions to the Closest Peer Firm's Analyst Revisions. Accounting and Business Research, http://dx.doi.org/10.2139/ssrn.2813244.

Irani, A.J. \& Karamanou, I., 2003. Regulation fair disclosure, analyst following, and analyst forecast dispersion. Accounting Horizons, 17, 15-29.

Johnson, E.S., 2013. Do changes in the SG\&A ratio provide information about changes in future earnings, analyst forecast revisions and stock returns? University of Arkansas, ProQuest, UMI Dissertations Publishing. Available at: http://search.proquest.com/docview/1437212307.

Ketchen, D.J. \& Palmer, T.B., 1999. Strategic responses to poor organizational performance: A test of competing perspectives. Journal of Management, 25, 683-706.

Khan, M. \& Watts, R.L., 2009. Estimation and empirical properties of a firm-year measure of accounting conservatism. Journal of Accounting and Economics, 48, 132-150.

Kim, J.-Y., Finkelstein, S. \& Haleblian, J., 2015a. All Aspirations are not Created Equal: The Differential Effects of Historical and Social Aspirations on Acquisition Behavior. Academy of Management Journal, 58, 1361-1388.

Kim, J., Kim, S., Ki, E. \& Zhou, J., 2015b. Cost stickiness and financial analysts' information environment. Working paper. Available at SSRN: http://ssrn.com/abstract=2641454.

Kondra, A.Z. \& Hinings, C.R., 1998. Organizational Diversity and Change in Institutional Theory. Organizational Studies, 19, 743-767.

Lambert, R.A., Leuz, C. \& Verrecchia, R.E., 2012. Information asymmetry, information precision, and the cost of capital. Review of Finance, 16, 1-29.

Lang, M. \& Lundholm, R., 1993. Cross-Sectional Determinants of Analyst Ratings of Corporate Disclosures. Journal of Accounting Research, 31, 246-271.

Lang, M.H., Lins, K.V. \& Miller, D.P., 2003. ADRs, Analysts, and Accuracy: Does Cross Listing in the United States Improve a Firm's Information Environment and Increase Market Value? Journal of Accounting Research, 41, 317-345.

Lant, T.K., 1992. Aspiration Level Adaptation: An Empirical Exploration. Management Science, 38, 623-644.

Larcker, D.F., 2003. Discussion of "are executive stock options associated with future earnings?". Journal of Accounting and Economics, 36, 91-103.

Lazere, C., 1995. Spotlight on SG\&A. CFO, 11, 39-45.

Lazere, C., 1996. Spotlight on SG\&A. CFO, 12, 28-34.

Lehavy, R., Li, F. \& Merkley, K., 2011. The effect of annual report readability on analyst following and properties of their earnings forecast. The Accounting Review, 86, 10871115.

Lev, B., 1969. Industry Averages as Targets for Financial Ratios. Journal of Accounting Research, 7, 290-299.

Lev, B. \& Sougiannis, T., 1996. The capitalization, amortization, and value-relevance of R\&D. Journal of Accounting and Economics, 21, 107-138.

Lev, B. \& Thiagarajan, R., 1993. Fundamental Information Analysis. Journal of Accounting Research, 31, 190-215. 
Lewbel, A., 1997. Constructing instruments for regressions with measurement error when no additional data are available, with an application to patents and R\&D. Econometrica, $65,1201-1213$.

Li, F., 2008. Annual report readability, current earnings, and earnings persistence. Journal of Accounting and Economics, 45, 221-247.

Liu, X.G. \& Natarajan, R., 2012. The effect of financial analysts' strategic behaviour on analysts' forecast dispersion. The Accounting Review, 87, 2123-2149.

Lobo, G.J., Song, M. \& Stanford, M., 2012. Accruals quality and analyst coverage. Journal of Banking and Finance, 36, 497-508.

Lobo, G.J. \& Zhou, J., 2001. Disclosure quality and earnings management. Asia-Pacific Journal of Accounting \& Economics, 8, 1-20.

Louis, H., Sun, A.X. \& Urcan, O., 2013. Do Analysts Sacrifice Forecast Accuracy for Informativeness? Management Science, 59, 1688-1708.

March, J.G. \& Simon, H.A., 1958. Organizations Oxford, England: Wiley organizations.

McNichols, M.F., 2002. Discussion of the Quality of Accruals and Earnings: The Role of Accrual Estimation Errors. The Accounting Review, 77, 61-69.

Messier, W., 2000. Auditing and assurance services: A systematic approach: McGraw-Hill.

Mintz, L.S., 1994. Spotlight on SG\&A. 10, 63-65.

Moliterno, T.P., Beck, N., Beckman, C.M. \& Meyer, M., 2014. Knowing your place: Social performance feedback in good times and bad times. Organization Science, 25, 16841702.

Morris, M., Schindehutte, M. \& Allen, J., 2005. The entrepreneur's business model: toward a unified perspective. Journal of Business Research, 58, 726-735.

Ou, J.A. \& Penman, S.H., 1989. Financial statement analysis and the prediction of stock returns. Journal of Accounting and Economics, 11, 295-329.

Panagiotou, G., 2007. Reference theory: strategic groups and competitive benchmarking. Management Decision, 45, 1595-1621.

Penman, S., 2016. Valuation: Accounting for Risk and the Expected Return. Abacus, 52, 106130.

Porac, J.F., Thomas, H., Wilson, F., Paton, D. \& Kanfer, A., 1995. Rivalry and the industry model of Scottish knitwear producers. Administrative Science Quarterly, 40, 203-227.

Porac, J.F., Wade, J.B. \& Pollock, T.G., 1999. Industry Categories and the Politics of the Comparable Firm in CEO Compensation. Administrative Science Quarterly, 44, 112144.

Raghuram, R. \& Servaes, H., 1997. Analyst Following of Initial Public Offerings. Journal of Finance, 52, 507-529.

Roberts, K., Rich, V.\& Krishnan, S., 2011. Are we yet there? Achieving optimal SG\&A spend for U.S. companies. Available at: http://www.alixpartners.com/en/LinkClick.aspx?fileticket=iuFgajYgKq8\%3D\&tabid= $\underline{635}$.

Roychowdhury, S., 2006. Earnings management through real activities manipulation. Journal of Accounting and Economics, 42, 335-370.

Schimmer, M. \& Brauer, M., 2012. Firm performance and aspiration levels as determinants of a firm's strategic reporsitiioning within strategic group structures. Strategic Organization, 10, 406-435.

Shaw, K.W., 2003. Corporate disclosure quality, earnings smoothing, and earnings' timeliness. Journal of Business Research, 56, 1043-1050.

Shinkle, G.A., 2012. Organizational aspirations, reference points, and goals: Building on the past and aiming for the future. Journal of Management, 38, 415-455. 
Staiger, D. \& Stock, J.H., 1997. Instrumental variables regression with weak instruments. Econometrica, 65, 557-586.

Sudharshan, D., Furrer, O. \& Arakoni, R.A., 2013. Robust imitation strategies. Managerial and Decision Economics, doi: 10.1002/mde.2657.

Washburn, M. \& Bromiley, P., 2012. Comparing aspiration models: The role of selective attention. Journal of Management Studies, 49, 896-917.

Weiss, D., 2010. Cost behaviour and analysts' earnings forecast. The Accounting Review, 85, 1441-1471.

White, D. \& Dieckman, E., 2005. Seizing control of SG\&A. Financial Executive, 21, 20-23.

Wooldridge, J.M., 2002. Econometric Analysis of Cross Section and Panel Data: Cambridge, Massachusetts.

Yu, F., 2008. Analyst coverage and earnings management. Journal of Financial Economics, $88,245-271$.

Yu, M., 2010. Analyst forecast properties, analyst following and governance disclosures: A global perspective. Journal of International Accounting, Auditing and Taxation, 19, 115.

Zhang, X.F., 2006. Information uncertainty and stock returns. The Journal of Finance, 61, 105137. 